NBER WORKING PAPER SERIES

\title{
UNIVERSAL CHILDCARE, MATERNAL LABOR SUPPLY AND FAMILY WELL-BEING
}

\author{
Michael Baker \\ Jonathan Gruber \\ Kevin Milligan \\ Working Paper 11832 \\ http://www.nber.org/papers/w11832 \\ NATIONAL BUREAU OF ECONOMIC RESEARCH \\ 1050 Massachusetts Avenue \\ Cambridge, MA 02138 \\ December 2005
}

We thank Pierre Brochu, Ekaterina Chmatova, Emily Hanna, Alfred Kong, Jennifer Rae, and Byron Shaw for excellent research assistance. We also gratefully acknowledge the research support of SSHRC (Baker Grant \#410-2002-0707, \#410-2005-0486, Milligan Grant \#410-2002-0299). We also thank seminar participants at the NBER, Cornell University, MIT, the University of Victoria, and the UBC empirical lunch. Finally, we thank the staffs of the Toronto and B.C. Research Data Centres for their technical support. This paper represents the views of the authors and does not necessarily reflect the views of Statistics Canada. The views expressed herein are those of the author(s) and do not necessarily reflect the views of the National Bureau of Economic Research.

(C2005 by Michael Baker, Jonathan Gruber, and Kevin Milligan. All rights reserved. Short sections of text, not to exceed two paragraphs, may be quoted without explicit permission provided that full credit, including (C) notice, is given to the source. 
Universal Childcare, Maternal Labor Supply, and Family Well-Being

Michael Baker, Jonathan Gruber, and Kevin Milligan

NBER Working Paper No. 11832

December 2005

JEL No. H2, J2

\begin{abstract}
The growing labor force participation of women with small children in both the U.S. and Canada has led to calls for increased public financing for childcare. The optimality of public financing depends on a host of factors, such as the "crowd-out" of existing childcare arrangements, the impact on female labor supply, and the effects on child well-being. The introduction of universal, highlysubsidized childcare in Quebec in the late 1990s provides an opportunity to address these issues. We carefully analyze the impacts of Quebec's “\$5 per day childcare” program on childcare utilization, labor supply, and child (and parent) outcomes in two parent families. We find strong evidence of a shift into new childcare use, although approximately one third of the newly reported use appears to come from women who previously worked and had informal arrangements. The labor supply impact is highly significant, and our measured elasticity of 0.236 is slightly smaller than previous credible estimates. Finally, we uncover striking evidence that children are worse off in a variety of behavioral and health dimensions, ranging from aggression to motor-social skills to illness. Our analysis also suggests that the new childcare program led to more hostile, less consistent parenting, worse parental health, and lower-quality parental relationships.

Michael Baker

Department of Economics

University of Toronto

150 St. George Street

Toronto, Ontario M5S 3G7 CANADA

and NBER

baker@chass.utoronto.ca

Jonathan Gruber

MIT Department of Economics

E52-355

50 Memorial Drive

Cambridge, MA 02142-1347

and NBER

gruberj@mit.edu

Kevin Milligan

Department of Economics

University of British Columbia

\#997-1873 East Mall

Vancouver, B.C.

CANADA V6T1Z1

and NBER

kevinmil@interchange.ubc.ca
\end{abstract}


There has been a substantial rise in the share of mothers who work in the paid labor force in North America. In the U.S., the share of mothers with children under age 6 who worked rose from $34 \%$ in 1976 to $56 \%$ in 2004 . In Canada, the employment rate of mothers with at least one child younger than 6 rose from $31 \%$ in 1976 to $67 \%$ in 2004 . In neither country has this trend been offset by a decline in the proportion of working fathers, necessitating an increased use of paid and unpaid childcare. In 1984, 37\% of children in the U.S. under age 6 were being cared for by someone other than a parent; by 2001 the proportion had increased to $56 \%$. In Canada, the comparable percentages rose from $40 \%$ in $1994-95$ to $51 \%$ in $2002-03$. $^{1}$

The increased demand for childcare accompanying the rise of two-earner couples has captured the attention of public policy makers. In both Canada and the United States, most childcare is provided by the private market. An alternative model is supplied by the universal public programs found in Europe (OECD, various years). Publicly-financed systems can provide more equitable access to quality childcare. This is important if there are cost barriers for low income families. Furthermore, given the evidence that the labor force decisions of secondary earners are very sensitive to their net earnings, subsidizing childcare can raise labor supply. Finally, childcare may improve child outcomes. Children in care may have better social or educational outcomes, or they may benefit from the additional income from secondary earners' labor supply.

That said, public systems require extensive public funding, which comes at a cost of higher taxes and therefore reduced economic efficiency. Moreover, it is possible that publiclyprovided childcare simply "crowds out" the private provision of care, with no net increase in

\footnotetext{
${ }^{1}$ The numbers in this paragraph are from the authors' calculations using the Current Population Survey (US) and Labour Force Survey (Canada) for mothers' labor supply, and the Survey of Income and Program Participation (US) and National Longitudinal Study of Children and Youth (Canada) for childcare use.
} 
childcare use or labor supply to the market. Finally, it is also possible that time spent in childcare, with many children per caregiver, is worse for children than time spent with parents at home.

A full evaluation of publicly-financed childcare, therefore, requires answers to three questions. First, does public financing affect the quality or quantity of care provided, or does it just lead to a substitution from one form of care to another? Second, if childcare use does increase, how large is the associated increase in labor force participation of parents, and what does it suggest about the net cost of the policy (subsidies offered minus new tax revenue collected)? Third, what effect does any change in childcare (and associated increases in labor force participation) have on child and family outcomes? Previous studies of childcare policy offer at best incomplete answers to one or two of these questions. There has been no evaluation of a full-scale public intervention which can address all three questions.

This paper provides such an evaluation using a major policy innovation in the Canadian province of Quebec in the late 1990s. The Quebec Family Policy began in 1997 with the extension of full-time kindergarten to all 5 year olds and the provision of childcare at an out-ofpocket price of $\$ 5$ per day to all 4 year olds. This $\$ 5$ per day policy was extended to all 3 year olds in 1998, all 2 year olds in 1999, and finally all children aged less than 2 in 2000. This dramatic policy change in one of Canada's largest provinces provides a promising quasiexperimental environment for evaluating the effect of publicly-financed childcare.

Our analysis is based on the National Longitudinal Survey of Children and Youth (NLSCY). The NLSCY is an ongoing panel data set which follows the progress of a large, nationally representative sample of Canadian children. We measure the impact of the policy change on mothers' labor supply, childcare utilization and child and parent outcomes. Because 
concurrent program reforms complicate the inference for single mothers, we focus on married (and cohabitating) women and their children.

Our results are striking. The introduction of universal childcare in Quebec led to a very large increase in the use of care. The proportion of $0-4$ year olds in care rose by 14 percentage points in Quebec relative to the rest of the country, or roughly one-third of the baseline childcare utilization rate. This rise in childcare was associated with a sizeable increase in the labor force participation of married women. Participation rose by 7.7 percentage points in Quebec, or about $14.5 \%$ of the baseline. The difference between the rise in participation and the rise in childcare utilization primarily reflects reduced use of informal childcare arrangements, or the "crowd out" of informal childcare by this new subsidized childcare. Partly as a result of this large "crowd out", the taxes generated by the new maternal labor supply fall far short of paying for the costs of the increased childcare subsidies.

We also find consistent and robust evidence of negative effects of the policy change on child outcomes, parenting, and parent outcomes. Child outcomes are worse for a variety of parent-reported measures, such as hyperactivity, inattention, aggressiveness, motor/social skills, child health status, and illness. Parental interactions with children are worse along all measured dimensions, and there is some evidence of deterioration in parental health and a reduction in parental relationship quality. These are subjective measures, but the consistency of the results suggests that more access to childcare is bad for these children (and, at least along some dimensions, for these parents). There are, however, interpretations of these findings which are more benign. While some of these explanations appear inconsistent with the data, we cannot rule out the possibility that our findings represent a short term adjustment to childcare, and not a long-run negative impact. 


\section{Section I: Previous Research on Childcare}

We have argued that to understand the effect of universal childcare subsidies, we need to answer three questions. In this section we review the answers provided in previous research.

\section{How Does Use of Childcare Depend on Its Price?}

This is the important first question to answer. If, in response to a subsidy, individuals use the same amount of childcare, or simply shift from unsubsidized to subsidized childcare, then the policy may be "crowding out" private childcare expenditures and have no net effect.

The estimates of own- and cross-price elasticities for childcare in the literature vary widely. Smaller estimates of the own price elasticity are reported by Blau and Hagy (1998) (-0.34) and Chaplin et al. (1999) (-0.405 for center based care). In contrast, Connelly and Kimmel (2003), Powell (2002), and Cleveland et al. (1996) all report estimates of -1.0 or larger. ${ }^{2}$ Michalopoulos and Robins (2000) report similarly large own price elasticities, but a smaller elasticity for income tax based childcare subsidies (most estimates smaller than -0.3). Some of these studies estimate separate elasticities for different types of care; Powell (2002) estimates larger elasticities for sitter care (greater than -3.0) while Michalopoulos and Robins's (2000) estimates for this type of care are not statistically significant. Blau and Hagy's (1998) estimates for different modes of care range from -0.07 to -0.34 , the largest for family home based childcare. Similarly, Michalopoulos and Robins (2000) find that tax subsidies have the largest effect on non relative, non center based care.

There are fewer estimates of cross-price elasticities of childcare demand. Michalopoulos and Robins (2000) report that center based care prices have statistically significant effects on the

\footnotetext{
${ }^{2}$ One difference between Blau and Hagy (1998), who report the smallest elasticity estimates, and other studies is that they have access to provider-reported price data. It is more common to construct childcare prices based on consumer reported expenditures and hours of use. However, Blau and Hagy obtain even smaller elasticity estimates when they instead construct childcare care prices based on consumer reported expenditures.
} 
use of relative and non relative care, but the prices of other types of care have negligible cross effects. Powell (2002) reports a cross price elasticities of center care on either relative or husband based care of roughly 1. Blau and Hagy (1998) report significant cross price effects, with the proportionate effects spread out fairly equally across competing types of care.

A problem with most of these elasticity estimates is that they are identified by variation in the childcare prices individuals report paying. Given the range of childcare options available, however, these observed prices are endogenous, and prices must be predicted for those not using care. Few if any studies have proposed a consistent instrument for either the price for those using care, or the predicted price for those not using care. ${ }^{3}$

Our work offers two clear advantages. First, the variation in childcare prices we exploit is more likely exogenous, conditional on the controls we can include in our estimating equation. Second, the depth of data on childcare use available to us means that we can explore the nature of the substitution among childcare modes when one price is changed. What is the Effect of Childcare subsidies on Work?

To the extent that childcare subsidies affect utilization of childcare, they may also influence the labor supply decisions of families. If childcare can be purchased in continuous units, then individuals requiring childcare to work face an effective wage which falls short of their nominal market wage by the hourly price of daycare. Daycare subsidies, therefore, increase an individual's effective wage by lowering the hourly daycare cost. This model predicts that an increase in the effective wage will increase labor market participation among affected individuals. The effect on individuals who are already working before the subsidy comes into effect is ambiguous if leisure is a normal good. There is a substitution effect raising hours of

\footnotetext{
${ }^{3}$ Blau and Hagy (1998) use regional variation in childcare prices as an instrument, but as we note below this is not likely to be exogenous to childcare utilization.
} 
work, but also an income effect working in the opposite direction. If childcare must be bought in discrete units (such as the full day) it can be modeled as a fixed cost of work, which raises individuals' reservation wages. A daycare subsidy reduces these fixed costs, lowering reservation wages, and raising labor market participation as before. The effect of the subsidy on those already working in this case is a straight income effect, which lowers hours of work if leisure is a normal good. ${ }^{4}$

There is a growing empirical literature that estimates the response of labor supply (typically female) to childcare costs using U.S. data (this literature is nicely reviewed by Anderson and Levine 2000, and Blau 2003). These studies can be divided into three types. The first evaluates welfare demonstration projects that include a childcare component. These studies typically report modest increases in labor supply among welfare recipients. The fact that childcare is only one element of the package of services provided, however, makes it difficult to infer the role of childcare per se.

The second type of study uses individual level variation in the "likely" costs of childcare, which are predicted using childcare cost equations estimated from a sample of working mothers. Identification of these equations requires finding determinants of childcare costs that are not also simultaneously determinants of the employment decision. Typically the cost of childcare in the local area or the number of children in the family is excluded from the employment equation. The number of children, however, clearly independently influences employment decisions. Also, the local area cost of childcare, the most common "instrument" in this approach, is correlated with factors that determine work decisions, such as area wages and the state of the local

\footnotetext{
${ }^{4}$ More complex, and realistic, models have been developed in the economics literature (eg. Heckman, 1974, Michalopoulos et al., 1992; for a full review of the literature, see Killingsworth and Heckman, 1986). These models accommodate the idiosyncrasies of particular programs or put the labor supply choice within a family context. Much of the intuition of the simpler formulation remains, however.
} 
economy. For example, places with tighter labor markets will have both more maternal labor supply, and higher childcare costs, but both are caused by the state of the economy. Perhaps as a result of this identification problem, the range of estimated elasticities of labor supply with respect to childcare costs from these studies is quite wide, stretching from 0 to -1.26 (Blau 2003). The smaller number of Canadian studies using this approach indicate a more modest response, the elasticities ranging from -0.156 to -0.388 (e.g., Cleveland et al.1996, Powell 1997 and Michalopoulos and Robins 2000).

A third type of study attempts to surmount these difficulties by finding exogenous variation in childcare costs. One example is Berger and Black (1992), who compare women receiving subsidized childcare to otherwise similar women who are on a waiting list for this care. They estimate an elasticity of employment with respect to subsidy rates of 0.094 to 0.35 . A second is Gelbach (2002), who uses variation in the quarter of birth of children as an instrument for whether they are enrolled in kindergarten at age 5 . He finds that there is a significant impact on labor supply of having one's child eligible earlier for kindergarten, with an implied elasticity of labor supply with respect to childcare costs of -0.13 to -0.36 . Thus, both of these studies report elasticities at the lower end of the range cited above. Yet both still have limitations. There are a number of reasons why those on waiting lists may not be an ideal control group for those accepted into the subsidy programs; see Parsons (1991) and Bound (1991) for a discussion of the issues in the context of the Disability Insurance program. The Gelbach study considers only five year olds, so that there is little guidance for children at younger ages who are at least of equal interest to policy makers.

Finally, concurrent with our analysis is a very recent paper by Lefevbre and Merrigan 
(2005) that also analyses the effect of this new Quebec policy. They use different data ${ }^{5}$ and focus exclusively on labor supply. There are also important differences in sample selection: they include single women, and also mothers of five year olds. We argue below that this larger sample may not appropriately identify the effect of the policy. They find positive effects of the policy on labor market participation ( 7 to 9 percentage points of a base of 0.53 ), annual hours worked (140-150 hours off a base of 980) and weeks worked (3 to 4.5 weeks off a base of 30), although the statistical significance of the some of these results varies by specification. Assuming daycare prices fell by 50 percent on average, the authors calculate elasticities from these results ranging from -0.25 to -0.34 .

\section{How Does Childcare Utilization Affect Child Development?}

The final question of importance for evaluating childcare subsidies is how childcare utilization affects child development. Parents who respond to subsidies by moving their children from home to subsidized childcare are substituting the care of others for their own care. Whether this substitution results in an increase or decrease in the net resources children receive depends on the quality of parental and non-parental childcare at stake. For example, non-parental care could have a positive effect in dysfunctional families, or help overcome some of the disadvantages of poverty. On the other hand, childcare at very young ages may limit the period that the child is breastfed, which may have detrimental consequences. At older ages, childcare may reduce the amount of time children receive direct interaction with, and stimulation by, an adult, since caregiver-child ratios are typically higher in childcare than in the average family. Finally, assuming that childcare is utilized to permit employment, there may be additional effects of employment on child well-being: more income may have positive effects, but more parental stress may have negative effects.

\footnotetext{
${ }^{5}$ Their analysis is based on the Survey of Labour and Income Dynamics.
} 
There has been an impressive amount of research on childcare and child development, mostly outside of economics but growing within economics as well. ${ }^{6}$ In the child development field, much research in the last decade has been based on a panel study by the National Institute of Child Health and Development Early Childcare Research Network. For example, NICHDECCRN (2003a) finds evidence that the amount of time through the first 4.5 years of life that a child spends away from his or her mother is a predictor of assertiveness, disobedience, and aggression. However, NICHD-ECCRN (2004) associates childcare with improved first grade performance. In both of these cases, family background characteristics are stronger predictors, but childcare is found to contribute independently. Another finding is a link from the quality of care to improved child outcomes. NICHD-ECCRN (2003b p. 467) concludes, however, that the evidence is ". . . mixed and the 'effect', if any, is not large ..." They do find stronger evidence for a link with cognitive development. A positive relationship between childcare quality and development is consistent with the results of other recent studies (Clarke-Stewart 1991, Field 1991).

Economic research has focused more closely on the effects of maternal employment on child development. The review offered by Ruhm (2004) identifies studies offering both positive (e.g., Vandell and Ramanan 1992, Parcel and Menaghan 1994) and negative (e.g., Leibowitz 1977, Stafford 1987, Mott 1991) effects of this employment on development, typically measured by the Peabody Picture Vocabulary Test performance of 3 and 4 year olds. Others offer mixed results that vary with the timing of work, or the specific group analyzed (e.g., Blau and Gossberg 1992, Waldfogel et al. 2002). Ruhm argues that a consensus view (e.g. Blau and Grossberg $1992)$ is that the net effects are small: positive effects of employment in the second and third

\footnotetext{
${ }^{6}$ One previous Canadian economic study (Lefebvre and Merrigan 2002) finds no relationship between the mode of childcare and social and motor development or developmental test scores.
} 
years offset negative effects in the first year. There is as yet limited evidence of longer term effects. Ruhm (2005) investigates the effects of maternal employment on development measured at ages 10 and 11 . He reports some modest negative effects on cognitive development of long hours of work in the infant and toddler years. Perhaps surprisingly, the larger adverse effects are found for more advantaged children. For Canada, Gagne (2002) finds little evidence of a link between maternal employment and child outcomes.

A potential weakness of any of this research is that maternal employment and variation in daycare mode and quality across children is typically a result of parents' choices. The estimated relationship between maternal employment or childcare quality and child development will therefore also capture any unobserved factors that are correlated with these variables. Families that choose paid childcare may be quite different than families that choose informal care; if paid care is viewed to be of higher quality, for example, families who choose paid care may be those that are more devoted to child quality along other dimensions as well. Moreover, if women who work are high ability in both the labor market and home production, maternal employment could be positively correlated with child outcomes although no causal link exists. It is also possible that pre-existing differences in the types of children in non-parental or parental care bias results. Norberg (1998) provides evidence that the mothers of high risk and developmentally challenged children are slower to return to work. This would positively bias any relationship between maternal employment and cognitive development.

Researchers are aware of these concerns about causality. NICHD-ECCRN (2003ab) directly address the issue and argue that their methodology, including controls for family background among other strategies, increases the plausibility of a causal link. Still, NICHDECCRN (2003a) cautions that, "the correlational nature of our longitudinal data does not permit 
an unambiguous determination of causal direction."

\section{Section II: The Policy Change}

To provide plausible causal inferences from the data, our empirical strategy is informed by the details of both the Quebec Family Policy and concurrent changes to the policy environment of families in Quebec and the rest of Canada.

Quebec's Universal Daycare Plan

In 1997, the government of Quebec introduced a new set of family policies, including large changes to government subsidies for childcare. The centerpiece was a childcare program to provide regulated childcare spaces to all children aged 0 to 4 in Quebec at a parental contribution of $\$ 5$ per day. ${ }^{8}$ Children were eligible whether or not the parents were working. The program was phased in, starting with four year olds in September 1997. Subsequently, three year olds became eligible in September 1998, two year olds in 1999 and children aged zero and one in September $2000 .^{9}$

The provision of new subsidized places was accomplished through a fundamental reorganization of the childcare sector in Quebec. A new Ministry was created, the Ministère de la Famille et de l'Enfance, to oversee the system. Centres de la petite enfance (Centers for young children - known by the acronym CPE) were created out of existing non-profit childcare centers to serve as organization nodes of the new system. In additional to providing childcare services, these centers oversaw networks of in home childcare providers. To be eligible to offer subsidized

\footnotetext{
${ }^{7}$ A related literature in economics examines the relationship between Head Start and other early child intervention programs and child development; the literature is reviewed by Karoly et al. (1998) and Blau (2003). This literature more directly addresses identification concerns, through random assignment or sibling comparisons (e.g. Currie and Duncan, 1995).

${ }^{8}$ In 2004 , the price was increased from $\$ 5$ to $\$ 7$ per day. Since this change occurred after the time period covered by our data, we refer to the $\$ 5$ amount in this paper.

${ }^{9}$ A further subsidy is available to families who cannot afford the $\$ 5$ per day fee, reducing the cost to $\$ 0$. A very small number of children receiving this waiver has been very small: 5,000-9,000 (Lefevbre and Merrigan 2005).
} 
places, in home providers had to affiliate with a CPE, and be subject to the associated regulations.

The transition to the new system created frictions. Even though the introduction was staggered by age, demand has exceeded supply leading to some queues. ${ }^{10}$ The response to this excess demand has been to create new subsidized childcare places. In Figure 1 we graph the total number of regulated places in the province as of March 31 in each year, and starting in 1998 the number of these places available at the subsidized rate. ${ }^{11}$ The number of spaces more than doubles between 1997, the last year before the new policy comes into effect, and 2005. Note, however, that the growth does not begin in earnest until 1999 - the annual increase in 1998 was only about 4 percent.

The expansion was accomplished by quadrupling the number of places in family based childcare, and doubling the number in CPEs. The greater expansion of family based childcare may reflect both the flexibility of expansion in this sector and parental preferences: a survey of parents in the province in 1999 revealed that they preferred family childcare for infants and center-based care at older ages.

In contrast to the growth in the CPEs, the for-profit sector has not expanded. The number of spaces in these centers was frozen from 1999-2003, reflecting a government preference that early childhood education occur in a non-profit setting where parents have greater involvement. The reality has been, however, that the majority of places in the for-profit sector have been 'leased' to the government and made available to parents at the subsidized rate. Thus in Figure 1 almost all regulated spaces are available at the subsidized rate in most years.

\footnotetext{
${ }^{10}$ Excess demand is hard to gauge, as documented estimates of the queues are unavailable. Waiting lists may include children already in a subsidized spot but wanting to change centers, duplicate counts of children on multiple waiting lists, or children during the transition period who are not yet eligible. Media reports suggest the queue may be as high as 35,000 children (CBC News Online 2005).
} 
In addition to increasing the quantity of places, there has been some emphasis on increasing the quality of care. Part of this has come through regulatory changes. Formal qualifications were raised for both CPE and family caregivers. ${ }^{12}$ The government has also implemented new wage policies in the sector to make it a more attractive profession: phased in over a four year period starting in 1999, it resulted in an average wage increase of 38 to 40 percent (Tougas 2002). On the other hand, several operational parameters were relaxed that may have decreased the quality of care. ${ }^{13} \mathrm{We}$ offer some direct evidence below that suggests that quality of childcare in Quebec along measured dimensions was not falling relative to the rest of Canada over this period.

The new Family Policy also included measures for school age children. The main components are a) voluntary full day kindergarten for five year olds (starting September 1997), b) half day kindergarten and free care for four year olds from disadvantaged areas, and c) subsidized after school childcare for children aged five through 12 (also at the $\$ 5$ per day rate). Enrolment in all three of these programs has risen sharply (Quebec 2005). Effects on the Price of Childcare

Prior to 1997 (and for families without subsidized places post 1997), direct subsidies for childcare were available for low income families. For example, in 1998, a full subsidy of up to $\$ 16.14$ per day was available to married parents with annual incomes up to $\$ 14,400$. This was reduced for family income over that threshold, at a rate of 40 cents for each $\$ 500$ of annual

\footnotetext{
${ }^{11}$ Prior to 1998 some places were available at a reduced rate through the programs in place before the CPE program.

${ }^{12}$ Two-thirds of staff must have a college diploma or university degree in early childhood education; previously the standard had been one-third. The government now provides financial support for childcare providers who are enrolled in college level courses in Early Childhood Education. Family childcare providers registered with a CPE faced increased training ( 24 hours to 45 hours) and annual professional development (6 hours) requirements.

${ }^{13}$ Maximum facility size was raised from 60 to 80 places. Staff/child ratios remained unchanged with the exception of four and five year olds whose ratio was raised from 1:8 to 1:10. Parent involvement in the board of directors was raised from $51 \%$ of members to two-thirds of members. The duration of center operating permits was lengthened from two to three years.
} 
income. There were also refundable tax credits at a rate that depended on family income; from $75 \%$ for those with the lowest incomes down to $26 \%$ for those with family incomes greater than $\$ 48,000$. These policies provided lower income families with a substantial subsidy before the introduction of the $\$ 5$ program. A full description of these tax subsidies to childcare is provided in Appendix B.

Under the new Family Policy, children in a $\$ 5 /$ day place are not eligible for any further direct subsidy. ${ }^{14}$ In addition, the $\$ 5$ parental contribution is not eligible for the provincial tax credit for childcare expenses, although it remains eligible for a federal deduction. The fact that the pre 1997 childcare policies targeted low income families implies that the effect of the Family Policy on the effective price of childcare varies with family income. Government estimates at the time the new policy was introduced indicate, for example, that single parents with one child would actually pay more for childcare up to annual incomes of about $\$ 20,000$ (Quebec 1997). At higher incomes, the decrease in the direct cost of childcare could be substantial, although attenuated by the fact that the costs are no longer eligible for the provincial tax credit.

In Figure 2 we provide an indication of the trend in the effective subsidy of childcare prices by province over the 1990s. We graph the marrieds' rate for all provinces, in addition to the singles' rate for Quebec. The subsidies are calculated as the sum of the direct expenditure subsidy (the direct reduction in childcare price from either low-income subsidies or the $\$ 5 /$ day policy) and the tax subsidy (the tax deduction/credit for any remaining out of pocket costs). Subsidies in each province vary with family characteristics, so we compute the subsidies for the same set of families in each province; as a result, any variation across provinces captures only

\footnotetext{
${ }^{14}$ The government continues to provide subsidies to very low income families that cannot afford $\$ 5 /$ day. The number of families receiving this subsidy is very small (Lefebvre and Merrigan 2005).
} 
the differences in legislative environment. A full description of the simulation methodology is reported in Appendix B.

At the beginning of the time period, Ontario and Quebec have the highest subsidy rates to childcare expenditures by married couples, and the variation among the remaining provinces is minimal. In 1994 the subsidy rate in Quebec jumps above those in other provinces and then remains steady until the start of the Family Policy, as the generous refundable tax credit was put in place. With introduction of the Policy in 1997 the subsidy in Quebec begins an upward trajectory until it settles at almost three times the rate in other provinces by 2002 . The jump is not immediate because the slow phase-in of the new program meant that only four year old children were initially eligible for the $\$ 5$ subsidized program, while our simulation sample includes families with children age $0-4$. By 2001, children of all ages $0-4$ are eligible, and the Quebec line stabilizes at a subsidy rate of around 80 percent. This steep rise is in contrast to a relatively constant subsidy rate for married couples in other provinces over this time period.

For singles in Quebec, it is harder to see the impact of the Family Policy. As outlined above, single women typically qualified for substantial subsidies before the $\$ 5$ per day program was introduced. Therefore, in contrast to the case for married parents, singles in Quebec see a steady upward trend in their subsidy rate throughout the decade. This makes it harder to distinguish the effects of the Family Policy from secular trends for this group. This finding and contemporaneous policy changes affecting single families suggest that we focus our analysis on married families.

\section{Changes to Family Benefits}

In addition to the introduction of the universal childcare plan, there were several other changes to the benefits paid to families both in Quebec and the rest of Canada through the late 
1990s. Most important for our purpose is another plank of the Family Policy that replaced a small universal family benefit with a large means tested benefit. There were also changes in the federal tax treatment of families, as well as important changes in welfare policy.

Because these program changes are not our focus, we direct the interested reader to find the details in Lefebvre and Merrigan (2003). We want to ensure, however, that these changes do not confound our inference, and so in Table 1 we provide a summary of their overall dollar impact. To do this we consider a "typical" family with two children aged 3 and 8. In two parent families we assume the husband has earnings of $\$ 40,000$. This same family is put through our tax and benefit calculator to ascertain what benefits the family would be eligible for in Quebec and neighboring Ontario through the years 1992 to 2002. We perform the analysis separately for married and single women at 4 earnings levels from $\$ 0$ up to $\$ 60,000$.

Benefits for married women are in the top panel of Table 1. The main change for this group during the period is to federal child benefits. Initially the benefit targets lower income families; the difference in benefits between $\$ 0$ and $\$ 20,000$ of female earnings is substantial. As the full benefit entitlement becomes larger, however, families in which the mother has a higher income (e.g., \$20,000) begin to receive a significant benefit. Because this variation is national, it can be seen affecting women in Ontario and Quebec in a similar way. The only notable Ontario/Quebec difference is the universal family allowance and allowance for young children that was payable in Quebec until 1997. These benefits, however, were relatively small, amounting to only a few hundred dollars annually. For this reason, their end in 1997 is unlikely to confound our analysis.

Benefits for single women, in the bottom panel of Table 1, show much more provincial variation. In both Quebec and Ontario we see sharply increasing benefits for low income singles 
due to expansions of the federal Canada Child Tax Benefit and the introduction of the National

Child Benefit in the late 1990s. However, in Quebec there is a substantial additional increase for this group starting in 1998 due to the Family Policy's new family allowance that targets low income women. This provincial difference is far less evident at higher income levels because the new family allowance is phased out starting at $\$ 15,332$.

Beyond family benefits, welfare programs (called Social Assistance in Canada) vary at the provincial level. Through this time period, several provinces implemented reforms and rate changes to their Social Assistance programs. While married women are eligible, only a small proportion of married mothers receive Social Assistance benefits. In contrast, nearly half of single mothers in the late 1990 s received some Social Assistance. ${ }^{15}$

This policy environment can be summarized as one in which there is significant provincial heterogeneity in the rate of benefit changes for low-income single mothers. In contrast, the changes in benefits for married couples and higher income singles are much smaller and uniform across provinces - with the very important exception of the introduction of the universal \$5 per day childcare program in Quebec. ${ }^{16}$

\section{Section III: Data and Empirical Strategy}

\section{Data}

Our primary data set for this analysis is the National Longitudinal Study of Children and Youth (NLSCY), a nationally representative panel survey that follows cohorts of Canadian children, some from as early as birth. The survey is conducted bi-annually and currently the

\footnotetext{
${ }^{15}$ See Milligan and Stabile (2004) for more detail on Social Assistance in Canada in the late 1990s.

${ }^{16}$ An earlier policy intervention had an impact on children in Quebec. From 1988 to 1997, a 'baby bonus' of up to $\$ 8,000$ was paid upon the birth of a new child. Milligan (2005) finds that this program had a sizeable impact on fertility, particularly for higher order fertility. We control for the number of children in the family, so larger family sizes will not confound our estimates. Moreover, all children in our main age 0-4 sample were born after the program's introduction. The cancellation of the program might have led to fewer large families, but we find later in this paper that our results are not much different for children with and without siblings.
} 
$1994-95,1996-97,1998-99,2000-01$ and $2002-03$ waves are available. The sampling frame is the same as the Canadian Labour Force Survey, which excludes only residents of the three northern territories, institutions, the military, and Indian Reserves. The initial target population for the NLSCY survey was 0-11 year olds in 1994. This initial cohort is followed longitudinally across all five waves. Additionally, younger children have been added to each wave providing an increasingly wider cross-section snapshot of the child and youth population. For the first four waves, the dataset provides cross-sectional coverage of children from age 0 up to the oldest of the original cohort. In the $5^{\text {th }}$ wave, the sample includes children age $0-5$ in the cross-sectional component and the original longitudinal cohort who are ages 8 to 19 . Missing from the $5^{\text {th }}$ wave is coverage of 6 and 7 years olds.

The content of the NLSCY is deep. The dataset provides information on a rich set of childcare choices as well as tracking children's development, parental and teacher evaluations, test scores, and class rankings. The sample averages around 2,000 children at each age per year, although some provinces and age groups were oversampled in some waves. For this reason, we use the provided weights in all of the results presented here.

Our primary sample consists of children age 0 to 4 , although for some robustness checks we also make use of children age 6 to 11 . We exclude five year olds to isolate the effect of the childcare program from the effect of the expanded full day kindergarten. The main sample restriction is to include only children from dual-parent families, for the reasons outlined earlier. ${ }^{17}$ We also exclude children not resident in one of the ten provinces and those with missing data for the control variables described below. These latter exclusions amount to very few observations.

The NLSCY questions on childcare use are extensive. The initial question about use is 
asked of parents of children age 0 to $11 .^{18}$ This question acts as a 'gateway', as no further childcare questions are asked for those who respond in the negative. ${ }^{19}$ Those who answer in the positive are asked a series of questions about the modes of childcare used and for how many hours each is used. Information on the number of children in care and number of caregivers at the chosen facility is collected starting in the third wave of the survey, so we cannot use it to compare quality before and after the introduction of the $\$ 5$ program.

We classify the childcare modes into (a) institutional care, (b) care in the home, and (c) care outside the home. Institutional care includes daycare centers, before and after school programs, or nursery schools. The vast majority of children age 0-4 in this category is in daycare centers. For care in the child's or another's home, we observe whether it is provided by a relative and whether the caregiver is licensed. Because the care subsidized by the Family Policy can be provided both through CPEs and through licensed family-based providers, our focus is on institutional care and licensed care outside the home. Finally, we can also observe hours of childcare use per week.

For our analysis of maternal labor supply, we focus on both the extensive and intensive margins. The variables of interest are employment, weeks and hours of work, and maternal enrollment in school.

The third set of variables describes the child's development. Given the ages of the preschool children in our sample, we do not observe the test score or school performance measures that are favored by economists in this context. We do, however, have scores on the Peabody

\footnotetext{
${ }^{17}$ We code and refer to those in common-law relationships as 'married.' Under the Canadian Income Tax Act, common law status applies to relationships after 12 continuous months.

${ }^{18}$ The wording of the question is "Do you currently use childcare such as daycare, babysitting, care by a relative or other caregiver, or a nursery school while you (and your spouse/partner) are at work or studying?"

${ }^{19}$ This is important for understanding how an informal care arrangement might go unreported - the respondent might have answered affirmatively if asked directly if a family member cares for the child, but the respondent is not asked this question if he or she initially answers negatively to the 'gateway' question.
} 
Picture Vocabulary Test (PPVT), which is administered to children aged 4 and 5 in the survey. Fortunately, there is enormous expertise in other disciplines measuring behavioral outcomes of young children, and this expertise is incorporated into child behavior measures available in the NLSCY. In particular, the NLSCY asks parents a battery of questions about hyperactivity, general anxiety, separation anxiety, aggressiveness, and motor and social development. The survey provides aggregate scores for each behavioral category based on the answers. We also investigate a series of questions on child health, which ask about general health status, specific illnesses, and accidents.

The fourth set of measures attempts to capture the tone of the parent-child relationship. The NLSCY draws on "best practices" to measure consistency, hostile/ineffective parenting, and aversive interactions. Again we use aggregate scores based on the answers to sets of questions for each category. We also examine measures of parental health and the quality of the parents' relationship.

Empirical Strategy

Armed with these NLSCY data, we estimate difference-in-differences models comparing the outcomes in Quebec and the rest of Canada around the time of this reform. We denote the "pre-reform" period as waves 1 and 2 of the NLSCY, covering the period 1994-1995 to 19961997. The "post-reform" period is waves 4 and 5 of the NLSCY, from 2000-2001 and 20022003. For outcome variables such as childcare use, labor supply, or parent and child outcomes, the generic estimating equation at the individual level is

$$
\text { Outcome }_{i p t}=\text { Policy }_{p t}+\text { PROV }_{p}+Y_{E A R_{t}}+X_{i p t}+\varepsilon_{i p t} \text {. }
$$

where $i$ indexes individuals, $p$ indexes provinces, and $t$ indexes years. We include year and province dummies, along with a set of control variables $X_{i p t}$ for the parents' characteristics 
(education level, age group, and immigrant status), size of urban area, number of siblings, and the age and sex of the child. ${ }^{20}$ For the policy variable, we investigate two alternatives. The first is a dummy for being eligible for the $\$ 5$ per day program - meaning that the child is resident in Quebec in a time period when his or her age is eligible for the subsidized space. The second policy variable is the average subsidy rate for childcare expenses in a given province-year combination, as described in Appendix B. This measure is useful to more precisely quantify the impact of the policy on behavior. We can use the estimates from this specification to calculate elasticities to compare with the results of previous studies.

Since we control for fixed effects for each province and each year, the effect of the childcare policy in Quebec is identified by the change in Quebec, relative to other provinces, in 2000 or later relative to 1997 or earlier. In addition, for the models with the province-year subsidy rate, we incorporate variation in all provinces. Most of the variation in the subsidy rate models, however, still comes from Rest of Canada-Quebec comparisons (as is clear in Figure 2). We exclude the 1998-1999 wave of the data from the analysis. ${ }^{21}$ In principle, these data could be included, which would not only increase sample size, but also would allow us to exploit the "phase-in" of the policy across different age groups. However, because we only observe one period during the phase-in, a triple difference empirical strategy with controls for provincespecific time effects would result in identification coming solely from the age 3 and 4 year olds

\footnotetext{
${ }^{20}$ The parental education groups we define are high school dropout, high school graduate, some post-high school, university degree. The age groups are in five-year sets, starting with 16-20 and ending with 46-99. The urban area dummies are for five levels: rural, under $30,000,30,000$ to $99,999,100,000$ to 499,999 , and 500,000 plus. Siblings are controlled for with dummies for the number of younger siblings $(0,1,2$ or more) and another set for the number of same age or older siblings $(0,1,2$ or more).

${ }^{21}$ Our decision to exclude these data is consistent with the decisions of Lefebvre and Merrigan (2005) who analyse the policy using data from the Survey of Labour and Income Dynamics. In their work, they enter a separate dummy variable for the 1998 data and consistently find the estimate is statistically insignificant.
} 
who became eligible for the CPE program in wave $3 .^{22}$ As is clear in Figure 1, the increase in supply of subsidized childcare spaces lags the start of the program in September 1997. The net result is that estimates based only on this wave 3 variation reveal a change in the composition of childcare, but not in the overall use. ${ }^{23}$ While this is consistent with conversion of existing places into regulated places and with the lag in increase in overall supply, it provides a poor basis for evaluation of the effect of the phased-in CPE program.

A disadvantage of our identification strategy is that any Quebec specific shocks coincident with the Family Policy will bias our estimates. This is clearly an issue for single mothers, due to differential welfare reforms across the provinces, and province-specific reactions to changes in federal benefits. This is one of the reasons we exclude this group from the analysis. Because the family incomes of married women typically make them ineligible for active labor market programs, this group is affected very little by these policy changes.

Still, other province-specific shocks and trends may confound our analysis. We attempt to address this concern in a number of ways. First, we enhance our regression results with compelling graphical evidence of how maternal labor supply, childcare utilization and child outcomes deviate in Quebec and the rest of Canada with the advent of the new policy. The availability of data for two years before the policy change for most of our variables allows us to demonstrate that we are not just picking up long-running trends in differences between Quebec and the rest of Canada. Second, where possible, we use 6-11 year old children as a control group. Since these children were in the same economic environment, we can use them to check for false positives. More precisely, we use only 6-11 year olds who at ages 0-4 were not eligible for

\footnotetext{
${ }^{22}$ In waves 1 and 2, no children are eligible for the program. In waves 4 and 5 all age 0-4 children are eligible. Therefore, for these waves the Quebec*wave interaction picks up the effect of the CPE program, leaving the identification to come only from the age 3-4 group who were eligible in wave 3 .
} 
subsidized childcare under the new Family Policy, so that there is no potential 'contamination' of the control group from previous exposure. These children are still not an ideal control group, however, because as described above the Family Policy included subsidized after school care for children in this age group. This biases the results for the control group in the same direction as the treatment group, however, so that comparisons will only understate policy effects. Third, we try specifications in which we control for province-specific economic conditions through the use of the province-specific unemployment rate for prime-age males. Once again, this is not ideal to the extent that there may be spillovers of this policy to male labor supply, but such spillovers are likely to be small. ${ }^{24}$

Finally, an important issue with this type of difference-in-differences analysis is the correct computation of the standard errors to address both within province-year correlation across observations, as well as serial correlation within provinces across time. We follow the advice of Bertrand et al. (2004) for cases with a small number of treatment groups and collapse the time series information using a two step method. We first estimate equation (1) excluding the policy variable and province and year effects. We next average the residuals within the "before" and "after" periods by province, so there are only two observations per province. We then estimate a 20 observation regression of these averaged residuals on dummy variables for the after period and policy (or subsidy rate) and province dummies. ${ }^{25}$ Since this regression has only 8 degrees of freedom, our threshold of significance for t-tests is higher than usual, which we

\footnotetext{
${ }^{23}$ Estimates from the triple-difference regression including all waves indicate a zero impact on use, and offsetting changes composition: movement toward centre-based care (eight percentage points) and away from own home care ( 3 points) and other home care (5 points).

${ }^{24}$ We tried to explore this issue using measures of male labor supply in the NLSCY and found insignificant effects.

${ }^{25}$ Bertrand et al. (2004) demonstrate this method on data that has already been aggregated to the state/year level. The analogy here would be to average the residuals from the first stage at the province/wave level, and then average these mean residuals for each province in the before and after periods. Since we use weights (or sums of weights) in each step, the two methods produce results identical to the third decimal place. We also weight the observations in the second stage regression by the normalized sum of weights in each period/province cell.
} 
account for in presenting the results. As a point of comparison we have estimated equation (1) directly, clustering the standard errors by province/year. Most of the parameter estimates from this procedure are very similar to those we obtain from our two step method, but the standard errors are considerably smaller.

\section{Section IV: Childcare Use and Labor Supply}

\section{Childcare Use}

Table 2 presents the results for our childcare use variables. Each cell shows the coefficient of interest from a separate regression. The first column of results from the table shows the difference-in-difference estimates, while the second shows the results from the model that includes the province/year subsidy rate. We also report the pre-Family Policy mean of each dependent variable in Quebec. The last column contains the results for an alternative specification including the provincial unemployment rates.

The first row shows that the odds a child was in childcare rose by 14.7 percentage points in Quebec, relative to the remainder of Canada, after this policy change. This is a very sizeable increase which amounts to more than a third of the baseline rate of childcare utilization. The second column in the first row shows that that each $10 \%$ increase in the subsidy rate to childcare raises utilization by $4.6 \%$. The 1996 pre-reform mean subsidy rate in Quebec is 0.472 (making the price paid out of pocket 0.528 ) and the mean for 'in any care' is 0.415 . Combining these with our estimate implies an elasticity of childcare use with respect to its price of 0.58 , which is at the lower end of the range of estimated elasticities from previous work.

This result is illustrated in Figure 3, where we graph the rate of childcare utilization in Quebec and the rest of Canada across the NLSCY waves. Use of childcare falls modestly in Quebec relative to ROC between wave 1 and 2, and then rises in wave 3, although only 
marginally faster than in the ROC. In wave 4 and wave 5, however, care rises substantially in Quebec while remaining flat in the ROC. This figure clearly illustrates a trend break in the use of childcare in Quebec around the time of this policy.

The next two rows show the effect of the policy on the hours of childcare used. The number of hours per week, among those with positive hours, increases by 6.4 hours, which is approximately 47 percent of the mean. The third row contains estimates for a binary variable indicating whether care was used at least 20 hours a week, in an attempt to measure full time use. Interestingly, the coefficient on this variable is very similar to the coefficient for using any childcare at all, suggesting that the impact of the program was a shift to full-time use. ${ }^{26}$

The next rows in Table 2 show estimates of changes in the various types of childcare arrangements. There is a very large rise in institutional care that is essentially equal to the overall rise in childcare. This is puzzling given the increase in home-based care that was part of the $\$ 5$ per day program. The final three rows resolve the mystery. Care in others' homes didn't change, but there was a shift from care provided by relatives and non-licensed non-relatives to care provided by licensed non-relatives. So in addition to an increase in use of institutional care, there was a shift in home care to licensed non-relatives. Licensed non-relatives would include the family-based care associated with CPEs through the $\$ 5$ per day program. Clearly, this policy change had major effects on the use of childcare.

In the last column of Table 2 we present results showing the coefficient on the eligibility dummy in a regression in which we include the provincial unemployment rates. The policy coefficients change very little with this control included, indicating that local economic trends are not confounding our inferences. The (unreported) coefficients on the unemployment rate are

\footnotetext{
${ }^{26}$ Anecdotal evidence suggests that providers offer subsidized places primarily on a full time basis. This has led to criticism that the new policy does not serve part-time users well (e.g., Lefebvre 2004).
} 
statistically significant, pointing to a decrease in childcare use when the unemployment rate increases.

\section{Labor Supply}

Table 3 reports the effects of this policy on the labor supply of married women. ${ }^{27}$ The first two columns consider mothers of 0-4 year old children. There is a rise in the employment of married women in Quebec, relative to the rest of Canada, of 7.7 percentage points, or $14.5 \%$ of baseline participation. In subsidy terms, we find that each $10 \%$ subsidy raises maternal work by 2.4\%. Given the 1996 Quebec price mean of 0.528 and employment mean of 0.530 , this implies an elasticity of maternal work with respect to childcare costs of 0.236 , which is towards the low end of estimates in the literature on labor supply effects of childcare costs. As Figure 4 shows, this change in labor force participation once again represents a trend break for Quebec relative to the rest of Canada: whereas female participation in Quebec was 5-6 percentage points below that in the rest of Canada before the policy, it is higher after the policy.

There is also a large rise in other measures of labor supply for married women. Average weeks of work rose by 3.5 , or more than $13 \%$ of baseline, for an elasticity of weeks of work with respect to childcare prices of 0.217 . The next three rows show the effect on part-time vs. fulltime work. There is an increase in the odds of women working more than 20 and more than 30 hours per week that is comparable to the entire rise in employment, but no effect on the odds of working more than 40 hours per week, suggesting that women were moving from no work to full-time work as a result of this policy change. Finally, there is no effect on the odds that the mother is enrolled in school.

\footnotetext{
${ }^{27}$ Since our sample for all of the other analyses in this paper is at the child-level, we use a comparable sample here, whereby each observation is the labor supply of a child's mother. This means that if a woman has more than one child aged $0-4$, she will be included in the data set multiple times. We have also estimated models that only use one observation for each woman, and the results are very similar.
} 
It is notable that the impact of the program on labor supply is only about half as large as the impact of the program on childcare utilization in absolute terms. There are two possible explanations for this finding. First, many women may be using childcare without working (although the question in the survey asks specifically about care only while working or at school). The other possibility is a change in reporting: some women may have been using informal childcare that was not reported, but as they switched to the formal sector they report their care.

The next rows of Table 3 investigate these two hypotheses by dividing the sample of mothers into four groups: working and using childcare; working and using no childcare (presumably a mismeasurement that is proxying the informal care of these $0-4$ year old children); not working and using childcare; and not working and using no childcare. The first two rows show that there is a reduction of 4.9 percentage points in the share of women who report working with no childcare for their small children, and the share who report working with childcare rises by 12.6 percentage points (the sum of these is the 7.7 percentage point increase in work). Thus, roughly one-third of the 14.7 percentage point rise in childcare use reported in the first row of Table 2 appears to be a shift from unreported informal care to more formal care ("crowding out" of informal care) rather than a net increase in childcare use. ${ }^{28}$ Assuming that the change in working without care is mismeasurement, we calculate an adjusted elasticity of childcare use with respect to price of 0.28 , compared to the estimate 0.58 we obtained interpreting the entire change in reported care as true. Finally, the third row shows that there is a small increase in the share of women who use childcare but do not work of 2.3 percentage points.

\footnotetext{
${ }^{28}$ To investigate this mismeasurement further, we isolated the set of women who worked full time, daytime shifts and were partnered with a man working likewise. The proportion of women reporting no childcare use in this subsample was similar.
} 
These findings frame our investigation of child outcomes. This policy is not purely an instrument for increased childcare use and labor supply. Rather, the effect of the policy is a mix of increased labor supply, leading to more childcare use, a shift in the mode of childcare (from informal to formal care), and a small rise in childcare use without increased labor supply. This means that the outcome results are only interpretable as a reduced form response to the policy, and not a structural effect of either increased labor supply or increased childcare use per se.

We have two specification checks for our labor supply results: the labor supply of mothers of older children and the addition of the provincial unemployment rate as a control variable. We begin with the results for the labor supply of mothers of children ages 6-11 in column three (excluding 5 year olds due to the introduction of all day kindergarten, and also excluding women with younger children who were by virtue of their age eligible for the CPE program.). As noted above this is not the ideal control group because the Family Plan provided subsidized after-school care at these ages, which may raise the labor supply of these mothers. This bias, however, makes finding an impact of the policy on the mothers of older children more likely (and thus towards rejecting the specification check).

In fact, we find no significant positive labor supply effects, in any specification, for the control group. There are insignificant effects on working at least 20 or 30 hours, and a significant negative effect on working more than 40 hours, suggesting some reduction in labor supply intensity for these older mothers. There is also a significant negative effect on the odds that a mother is enrolled in school. This set of findings suggests that the results for labor supply causally reflect the increase in childcare access for $0-4$ year olds.

In the last column of the table are results for specifications including the provincial unemployment rate. The coefficients on mother working and on weeks worked drop by $22 \%$ and 
$14 \%$, but they retain their significance, and the other coefficients are not much affected. Again, this suggests our empirical strategy is robust to controls for the local economic environment.

\section{Net Program Cost}

A complete cost-benefit calculation for this policy intervention is beyond the scope of this paper. It would have to value and compare the consumption and investment return to staying home with one's child to the consumption and investment return to returning to work. Instead, we offer an estimate of the net budgetary cost of this program, accounting for offsetting tax revenues from increased maternal labor supply.

The example we study is set in 2002 . We consider a representative married working woman with a husband who also works. We assume the daily cost of childcare is $\$ 35$, of which $\$ 5$ is paid by the parents and $\$ 30$ by the government, for a subsidy rate of $0.857 .{ }^{29}$ Our estimated coefficient on the subsidy rate of 0.237 in Table 3 implies that the introduction of this subsidy led to $0.857 * 0.237=0.203$ more workers per child.

To estimate the tax revenues from these additional workers, we create a simulation using income microdata from the Survey of labour and Income Dynamics (SLID) and our tax and benefit calculator. ${ }^{30}$ From a representative sample of Quebec married families, we estimate that the per person income tax (combined federal and provincial) and payroll tax gained would be $\$ 8,010$ and the reduction in child benefits paid given the family's higher income would amount to $\$ 1,221.00$, totalling $\$ 9,231$. Multiplied by 0.203 more workers, this works out to an increase in government revenues of $\$ 1,874$ per child.

\footnotetext{
${ }^{29}$ The $\$ 30$ per day subsidy amount is for Quebec for children ages 18-59 months and comes from Friendly, Beach, and Turiano (2002). The $\$ 30$ amount does not include grants for fixed costs, so it represents a lower bound on the full cost of the subsidy.

${ }^{30}$ Using the SLID for 2002, we select all couples in Quebec with a child under age 5 and both parents working at least 50 weeks. This sample comprises 228 families. The average male earnings in this sample is $\$ 50,521$ and the average female earnings is $\$ 30,049$. We process these observations through the calculator and arrive at the total for
} 
The cost of this program is the $\$ 30$ dollars per day the government is now paying per child. The average employment rate of mothers of young children in Quebec in wave 5 of the NLSCY is 0.63 . So, this amounts to $(\$ 30 * 50$ weeks $* 5$ days $* 0.63) \$ 4,725$ effective cost per child. When compared to the change in taxes, we can now calculate that $(\$ 1,804 / \$ 4,725) 40$ percent of the costs of the childcare subsidy are covered by the income and payroll taxes on the extra labor the subsidy encourages. That is, the large shift from informal (unsubsidized) to formal (subsidized) childcare, as well as some increased childcare use by mothers who do not work, resulted in a significant net cost of this program, despite the large rise in labor supply.

\section{Section V: Child Outcomes, Parenting and Parent Outcomes}

\section{Child Outcomes}

As discussed in Section I, there is considerable controversy over the effects of maternal work and childcare use on child outcomes. The policy change in Quebec, along with the rich data on child outcomes available in the NLSCY, offers an opportunity to more completely address this important question.

Table 4 presents the results for child outcomes for the difference-in-differences specification. We consider several summary scores of the individual behavioural measures: hyperactivity-inattention; general anxiety; separation anxiety; physical aggressiveness / opposition; motor and social development; and the PPVT score. Appendix C shows how the indices are constructed from the underlying survey questions, and also provides estimates on the individual components using the same specification as we use for the scores. We also consider five measures of health: an indicator for excellent health; indicators for the child never having 
nose/throat or ear infections; an indicator for having an asthma attack in the last 12 months; and an indicator for injury in the last 12 months.

Many scores in the NLSCY are calculated separately for different age groups. Because we would like to use our age 6-11 control group, we also construct our own 'pooled' scores by taking the questions that were common between scores for two different age groups. For example, the hyperactivity-inattention score for 2-3 year olds differed from the score for 4-11 year olds by only one question. The 'pooled' hyperactivity score was formed by dropping the non-overlapping question from the score calculation. Not only do the pooled scores allow comparisons to age 6-11 children, but they also allow us to include age 4 children in the primary sample. On the downside, the pooled scores we construct are somewhat ad hoc and have not been through the rigorous testing that the NLSCY-provided scores have. Details on our constructions are provided in Appendix C.

The first results in Table 4 are for hyperactivity. Using the age 2-3 score, we find that children eligible for the subsidized place had a hyperactivity score 0.101 points higher than ineligible children, although the estimate is not significant. In the second row, we find a similar result for the 'age 4 and under' sample using the pooled score, and it is significant. The next two rows show parallel results for anxiety. Here the results are positive and significant in both cases (although only at the 10\% level for the 2-3 year olds, due to our small number of degrees of freedom). The next row shows a positive and insignificant effect on separation anxiety. The questions underlying this index are not asked of older children so we cannot construct a pooled score. The next two rows show positive and significant effects for aggressiveness both in the age 2-3 and pooled scores, while the next row shows a highly significant negative effect for motorsocial skills; motor-social skills questions are not asked of older children. Finally, the scaled 
PPVT score (available for four year olds only) is positive but small and very imprecisely estimated, rendering this result uninformative.

There are also sizeable negative effects on health indicators. There is a significant negative effect on the odds of being in excellent health of 5.3 percentage points. There are also large and significant reductions in the odds of never having infections. There is no significant effect on the incidence of asthma or injury.

Many of these estimated effects are small relative to the mean. These are reduced form estimates of the effects on all children (the intention to treat effect), however, not on the marginal children affected by the policy (the effect of the treatment on the treated). Measuring the effect of the treatment on the treated is quite difficult, however, since the treatment is not clear. Is the treatment increased exposure to parental labor supply, in which case $7.7 \%$ of children are treated? Or is the treatment increased use of childcare, in which case $14.7 \%$ of the children are treated? Or is the treatment either increased use of childcare or a shift in the site of childcare, in which case at least $19.5 \%$ of children are treated?

While we are unable to resolve this question, we can plausibly bound the effects by assuming that between $7.7 \%$ and $19.5 \%$ of children are treated. Doing so makes the effects appear quite large. For example, for motor/social skills, the estimates suggest that eligibility for the subsidized childcare plan leads to a $1.64 \%$ decline in skills relative to the mean, for an effect on the treated of between $8.4 \%$ and $21.2 \%$ relative to the mean. The effects are much larger for other behavioural measures. For example, for anxiety, the results imply a $12 \%$ rise relative to the mean score of 0.967 for the intention to treat effect; this implies that work/childcare use led to a $62.6 \%$ to $158.5 \%$ rise in anxiety for the treated. Some of the health effects are similarly quite 
large: the rise in the rate of nose/throat infection for all children is $30.4 \%$ of the pre-policy mean, suggesting a policy effect on the treated of $155.8 \%$ to $394.6 \%$.

Another way to calibrate the magnitude of the results is to compare the estimated effects to the coefficients on some of the control variables. For example, the pooled hyperactivity score coefficient of 0.143 implies a percentage increase in the range of $17.6 \%$ to $44.7 \%$ for the effect of the policy change on the treated. As a comparison, the estimated effect of the mother being a high school graduate instead of a dropout is -0.412 , which is a $9.9 \%$ change from the mean. Similarly, having a boy increases the pooled hyperactivity score by $12.7 \%$, using the same calculation. This suggests that the CPE program's effect on hyperactivity - even when we take the lower bound estimate - is larger than the effect of mother's high school completion or the boy-girl differential.

We again wish to check that the inferences from our difference-in-differences estimation are not spurious. In Figure 5, we present graphs of four of our outcome mesaures for Quebec and the rest of Canada over the waves of the survey. Hyperactivity and aggression actually fall in Quebec relative to the rest of Canada before the policy, but there is a sizeable relative rise in Quebec between waves 2 and 5. Anxiety follows a similar pattern in Quebec and the rest of Canada until wave 3, at which point it grows much more quickly in Quebec. Our indicators for the absence of nose and throat infections are flat in both Quebec and the rest of Canada through the first two waves, and then fall dramatically in Quebec in the post-policy period.

The results for 6-11 year olds, who were less affected by this policy change (but not unaffected due to the subsidization of after-school care) are in the third column of Table 4 . They are largely consistent with a causal interpretation of the estimates. For three of the six measures for which data on 6-11 year olds is available (hyperactivity, aggressiveness and injury) the 
estimates are wrong-signed, and the estimate for injuries is statistically significant. For excellent health, there is also a negative effect on 6-11 year olds, but it is much smaller than the effect on 0-4 year olds. For anxiety, however, there is a significant and large effect on 6-11 year olds which is of similar magnitude as the result for 0-4 year olds.

Finally, the estimates for specifications including the province unemployment rate are in the last column of Table 4 . Once again, the results are very similar, despite the fact that the unemployment rate itself is highly correlated with these outcomes. More than half of the coefficients are larger when we control for unemployment. The only coefficient that is reduced in a noticeable way are those on emotional disorder - anxiety (which roughly halves and becomes insignificant) for small children only; for the pooled sample, the result is very similar when we include the unemployment rate.

\section{Interpretation}

These results are striking in their consistent indication of a substantial negative impact of universal childcare on children in two parent families. Moreover, both the graphical evidence and the lack of consistent findings for 6-11 year olds confirm that this is a causal impact of the policy change. Nevertheless, this is a reduced form finding, and is subject to numerous interpretations. We discuss these interpretations, and data we can bring to bear on them, in this section.

First, it is possible that these findings are simply reporting artifacts. For example, higher exposure to childcare could lead to increased reports of bad outcomes with no real underlying deterioration in child behaviour, if childcare providers identify negative behaviours not noticed (or previously acknowledged) by parents. Alternatively, perhaps parents are more stressed due to increased family labor supply, so they are more likely to report negative child behaviors. 
While we can't rule out these alternatives, they seem unlikely given the consistency of our findings both across a broad spectrum of indices, and across the categories that make up each index (as shown in Appendix C). In particular, these alternatives would not suggest such strong findings for health-based measures, or for the more objective evaluations that underlie the motorsocial skills index (such as counting to ten, or speaking a sentence of three words or more).

If these results do reflect a real deterioration in the outcomes of small children, there remains the question of whether they represent short-run transitional problems or longer-run consequences. A simple mechanism for transitional problems would be initial costs of socialization. If all children have problems when they are first in a social environment interacting with other children, then perhaps all the Quebec policy did was bring forward this "day of reckoning"; moving these problems of kindergarten to an earlier age. In that case, the welfare implications of our findings are ambiguous. Indeed, it could actually be beneficial that this policy exposed children to these costs earlier on, so that they were better prepared for the educational and health consequences of attending school.

The best way to distinguish these views would be to examine the impact of this policy on the long-term outcomes of this exposed cohort. Unfortunately, the data to carry out this evaluation are not yet available. Nevertheless, a partial test of this particular socialization explanation is to compare children with and without siblings. Presumably, the socialization "shock" was larger for those without siblings, so this story would imply a larger effect on this group. We have estimated our models separately for those with and without siblings, finding no consistent evidence of a stronger effect on one group or another. While not ruling out the socialization story, this finding is not consistent with it. 
Even if these results do reflect true long-run negative consequences for children, important questions remain. Are they the consequence of increased maternal labor supply, increased childcare exposure, or a shift in the site of childcare? Do these findings apply only to middle to higher income married families, the population most directly affected by the policy and our focus here, or can they be extended to lower income and single-parent families, a population of independent policy interest? And do they reflect the peculiarity of the Quebec policy change: by significantly increasing demand for childcare spots over a short period, did the government lower the quality of the average childcare provided?

With only one policy "experiment" to evaluate, we cannot identify the structural channels of any negative effects; nor can we apply our findings out of sample to other populations. What we can do, however, is bring some evidence to bear on the third question, by examining the characteristics of childcare providers over time in Quebec and the rest of Canada. Using the Canadian Labour Force Survey, we evaluated the earnings, age, and education level of childcare workers over time across provinces. We found no evidence that childcare workers were becoming less qualified in Quebec over time - if anything, qualifications were rising relative to the rest of Canada. ${ }^{31}$

\section{Parenting and Parent Outcomes}

The NLSCY not only gathers data on child outcomes, but also on the quality of parental interactions with children and on the well-being of parents themselves. Both of these might plausibly be affected by increased use of childcare and labor supply induced by the $\$ 5$ per day

\footnotetext{
${ }^{31}$ We selected workers reporting NAICS code 6244 (Child day care services). Comparing changes in average values between 1994-1997 and 2000-2002 (to match our NLSCY data) we find the average age of childcare workers changes almost identically (and is almost identical) in Quebec and the rest of Canada, the proportion of workers who work full time rises more in Quebec (by 5 percentage points) and the proportion of workers with some postsecondary education rises by 26.7 percentage points in Quebec to reach $73.2 \%$, and rises by 21.3 points in the rest of Canada to reach 66\%. For earnings we can compare averages between 1996-1997 and 2000-2002. Earnings rise in Quebec by 12 percent (nominally) and fall in the rest of Canada by 6 percent.
} 
program. We use three measures of the quality of parental interactions provided by the NLSCY: "hostile and ineffective parenting"; "parental consistency"; and "aversive parenting."32 These indices are aggregated from parental responses to individual questions listed in Appendix C; once again, while subjective, they represent the views of experts on the best indicators of the quality of parent-child relationships.

Table 5 presents difference-in-differences estimates of the effects of the policy change on these indicators of parental interaction quality. For each of these scales, there is strong evidence of "worse" parenting after the new policy was put in place. There is a significant rise in the hostile/ineffective parenting index of about $8.7 \%$ of its baseline value, a significant decline in the consistent parenting index of about $3.6 \%$ of its baseline value, and a significant rise in aversive parenting of about $2.2 \%$ of baseline. We plot the time trends for the three parenting measures in Figure 6. While aversive parenting shows little closing of the Quebec - rest of Canada gap, the other measures show remarkable changes consistent with the parent-child relationship getting worse in Quebec in waves 4 and 5.

Once again, for these measures we can examine the impact on the parenting of older children and try conditioning on the provincial unemployment rate to assess whether there are omitted factors specific to Quebec or the rest of Canada affecting our results. For hostile/ineffective parenting, there is a positive effect on older children, but it is much smaller than for younger children. For the other two indicators, the effect is opposite signed for older children, indicating a possible trend in the opposite direction. When we include the provincial unemployment rate in the last column, some of the coefficients get larger while others get smaller, but the pattern of results and significance holds (with the exception of aversity, which

\footnotetext{
${ }^{32}$ There is also a measure of "positive interactions" available in the data which shows strong negative effects, but this is mechanically related to time exposure to children and so is not very indicative of a deteriorating relationship
} 
becomes insignificant). The robustness checks indicate that, for these measures, we have strong evidence that this policy change led to worsening parent-child interactions along dimensions validated by experts on children and parenting.

The remaining rows of Table 5 consider the effects on measures of parental well-being. The self-assessed health status of the mother and father is available in the NLSCY, along with a depression score for one of the parents. (We present the depression results only for mothers, since the mother was the primary respondent in the vast majority of families.) In addition, the survey contains a question about the satisfaction of the survey respondent with their spousal relationship, on a scale of 1-11.

The estimated coefficients indicate a deterioration in paternal health around the time of this policy, with a reduction of 2.8 percentage points in the odds that the father reports himself in excellent health. For mothers, the estimated effect on self-reported health is smaller at -0.011 , and not statistically significant. For mothers, however, we have striking evidence of an increase in depression: the mother's depression score is estimated to increase by 0.428 , or $10.2 \%$ of the mean. There is also a very striking negative effect on reported relationship satisfaction. The fifth column once again shows the effect on parents of older children; this indicates that the results for father's and mother's health status may not be reliable, but that there is no parallel effect in the families with older children for either maternal depression or relationship quality. The results are also very robust to including province/year unemployment rates. Overall, these estimates provide some evidence of a detrimental impact of the program on parental health, most convincingly for mothers' mental health, and on relationship satisfaction.

\section{Part VI: Conclusion}

In this paper we provide, to our knowledge, the first comprehensive analysis of a 
universal subsidized childcare program, following its impact from childcare use through employment and finally to children's and parent's outcomes. We uncover strong evidence of a shift into new childcare use, although approximately one third of the newly reported use appears to come from women who previously worked and had informal arrangements. The labor supply impact is strongly significant, and our measured elasticity of 0.236 is slightly smaller than previous credible estimates. Finally, we report striking evidence that children's outcomes have worsened since the program was introduced. We also find suggestive evidence that families we study became more strained with the introduction of the program. This is manifested in increased aggressiveness and anxiety for the children, more hostile, less consistent parenting for the adults, and worse adult mental health and relationship satisfaction.

As discussed earlier, these results are subject to a number of interpretations that highlight the importance of future work in this area. Most importantly, it is not clear whether the negative child outcomes are short-run transitions or long-run effects. We also have no results for single parent families, a group that previous studies suggest can benefit from high quality childcare. In addition, we raise a puzzle here of why families would take advantage of a policy which leads to worse child outcomes, worse parenting, and worse parental outcomes. It is possible that the other unmeasured benefits of higher family incomes offset these costs. Alternatively, it is possible that families will learn that they are not better off in this new regime, and that ultimately use of subsidized childcare may fall. Once again, following the long-run evolution of these policy effects will be central to a full welfare analysis of the program. 


\section{References}

Anderson, Patricia M. and Phillip B. Levine (2000), “Childcare and Mothers' Employment Decisions," in David E. Card and Rebecca M. Blank (eds.) Finding Jobs: Work and Welfare Reform. New York: Russell Sage Foundation.

Berger, Mark C. and Dan A. Black (1992), "Childcare Subsidies, Quality of Care, and the Labor Supply of Low-Income, Single Mothers.” Review of Economics and Statistics, Vol. 74, No. 4, pp. 635-642.

Bertrand, Marianne, Esther Duflo, and Sendhil Mullainathan (2004), "How Much Should We Trust Difference in Difference Estimates?" Quarterly Journal of Economics, Vol. 119, No. 1, pp. 249-275.

Blau, David M, (2003), “Childcare Subsidy Programs,” in Robert Moffitt (ed.) Means-Tested Transfer Programs in the U.S. Chicago: University of Chicago Press.

Blau, David M. and Alison P. Hagy (1998), "The Demand for Quality in Childcare”, Journal of Political Economy, Vol. 106, No. 1, pp. 104-146.

Blau, Francine B. and Adam J. Grossberg (1992), "Maternal Labor Supply and Children's Cognitive Development.” Review of Economics and Statistics, Vol. 74, No. 3, pp. 474481.

Bound, John (1991), "The Health and Earnings of Rejected Disability Applicants: A Reply." American Economic Review, Vol. 81, No. 5, pp. 1427-1434.

CBC News Online (2005), "Day care in Canada." Indepth series, May $6^{\text {th }}$. Accessible at [http://www.cbc.ca/news/background/daycare/].

Chaplin, Duncan D., Philip K. Robins, Sandra L. Hofferth, Douglas A. Wissoker and Paul Fronstin (1999), "The Price Sensitivity of Childcare Demand: A sensitivity Analysis," unpublished manuscript.

Clarke Stewart, and K. Alison, (1991), "A Home is Not a School: The Effects of Childcare on Children's Development.” Journal of Social Issues, Vol. 47, No. 2, pp. 105-123.

Cleveland, Gordon, Morley Gunderson, and Douglas Hyatt (1996), "Childcare Costs and the Employment Decision of Women: Canadian Evidence." Canadian Journal of Economics Vol. 29, No. 1, pp. 132-148.

Connelly Rachel and Jean Kimmel (2003), "Marital Status and Full-time/Part-time Work Status in Childcare Choices," Applied Economics, Vol. 35, No. 7, pp. 761-77.

Currie, Janet and Duncan Thomas (1995), "Does Head Start Make A Difference?" American Economic Review, Vol. 85, No. 3, pp. 341-364. 
Field, Tiffany M. (1991), "Quality Day Care and Grade School Behavior and Performance." Child Development, Vol. 62, No. 4, pp. 863-870.

Friendly, Martha, Jane Beach, and Michelle Turiano (2002), "Early Childhood Education and Care in Canada 2001," Childcare Resource and Research Unit, University of Toronto.

Gagne, Linda (2002), "Parental Work, Child-care Use, and Young Children's Cognitive Outcomes," Research Data Centre Research Paper, Statistics Canada Catalogue No. 89594-XIE.

Gelbach, Jonah (2002). "Public Schooling for Young Children and Maternal Labor Supply." American Economic Review, Vol. 92, No. 1, pp. 307-322.

Heckman, James J. (1974), “Effects of Child-Care Programs on Women's Work Effort.” Journal of Political Economy, pp. s136-s163.

Karoly, Lynn A., Peter W. Greenwood, Susan S. Everingham, Jill Houbé, M. Rebecca Kilburn, C. Peter Rydell, Matthew Sanders and James Chiesa (1998), "Investing in Our Children: What We Know and Don't Know About the Costs and Benefits of Early Childhood Interventions.” Santa Monica CA: Rand Report MR-898-TCWF.

Killingsworth, Mark R. and James J. Heckman (1986), "Female Labor Supply: A Survey," in Orley Ashenfelter and Richard Layard (eds.) Handbook of Labor Economics, Vol. 1. Amsterdam: North Holland, pp. 103-204.

Lefebvre, Pierre (2004), “Quebec's Innovative Early Childhood Education and Care Policy and its Weaknesses," Policy Options, Vol. 25, No. 3, pp. 52-57.

Lefebvre, Pierre and Philip Merrigan (2002), "The Effect of Child Care and Early Education Arrangements on Developmental Outcomes of Young Children." Canadian Public Policy, Vol. 28, No. 2, pp. 159-186.

Lefebvre, Pierre and Philip Merrigan (2003), “Assessing Family Policy in Canada: A New Deal for Families and Children." Choices, Vol. 9, No. 5, Institute for Research on Public Policy.

Lefebvre, Pierre and Philip Merrigan (2005), "Low-fee (\$5/day/child) Regulated Childcare Policy and the Labor Supply of Mothers with Young Children: A Natural Experiment from Canada." Manuscript, Department of Economics, Université de Québec a Montréal.

Leibowitz, Arleen (1977), "Parental Inputs and Children's Achievement." Journal of Human Resources Vol. 12, No. 2, pp. 242-251.

Michalopoulos, Charles and Philip K. Robins (2000), "Employment and Child-Care Choices in Canada and the United States," Canadian Journal of Economics Vol. 33, No. 2, pp. 435- 
470.

Michalopoulos, Charles, Philip K. Robins, and Irwin Garfinkel (1992), “A Structural Model of Labor Supply and Childcare Demand," Journal of Human Resources, Vol. 27, No. 1, pp. 166-203.

Milligan, Kevin (2005), "Subsidizing the Stork: New Evidence on Tax Incentives and Fertility," Review of Economics and Statistics, Vol. 87, No. 3, pp. 539-555.

Milligan, Kevin and Mark Stabile (2004), "The Integration of Child Tax Credits and Welfare: Evidence from the National Child Benefit Program," NBER Working Paper No. 10968.

Mott, Frank L. (1991), “Developmental Effects of Infant Care: The Mediating Role of Gender and Health.” Journal of Social Issues, Vol 47, pp. 139-158.

NICHD - Early Childcare Research Network (2003a), "Does Amount of Time Spent in Childcare Predict Socioemotional Adjustment During the Transition to Kindergarten?, Child Development, Vol. 74, No. 4, pp. 976-1005.

NICHD - Early Childcare Research Network (2003b), "Does Quality of Childcare Affect Child Outcomes at Age 4 1/2?” Developmental Psychology, Vol. 39, No. 3, pp. 451-469.

NICHD - Early Childcare Research Network (2004), "Multiple Pathways to Early Academic Achievement” Harvard Educational Review, Vol. 74, No. 1, pp. 1-29.

Norberg, Karen (1998), “The Effects of Daycare Reconsidered.” NBER Working Paper \#6769.

OECD (various years). Babies and Bosses: Reconciling Work and Family Life. Paris: OECD.

Parcel, Toby L. and Elizabeth G. Menaghan (1994), "Early Parental Work, Family Social Capital and Early Childhood Outcomes", American Journal of Sociology, Vol. 99, pp. 972-1009.

Parsons, Donald O. (1991), “The Health and Earnings of Rejected Disability Insurance Applicants: A Comment." American Economic Review, Vol. 81, No. 5, pp. 1419-26.

Powell, Lisa M. (1997), "The Impact of Childcare Costs on the Labor Supply of Married Mothers: Evidence from Canada." Canadian Journal of Economics Vol. 30, No. 3, pp. 577-594.

Powell, Lisa M. (2002), "Joint Labor Supply and Childcare Choice Decisions of Married Mothers," Journal of Human Resources, Vol. 37, No. 1, pp. 106-128.

Quebec (1997), "New Elements of the Family Policy.” Secretariat of the comité des priorités of the ministère du Conseil executive. Les Publications du Québec, Canada: Sainte-Foy. 
Quebec (2005), "Education Indicators, 2005 Edition, Ministère de l'Éducation, du Sport et du Loisir, publication number 2005 - 05-00451.

Ruhm, Christopher J. (2004), "Parental Employment and Child Cognitive Development," Journal of Human Resources, Vol. 39, No. 1, pp. 155-192.

Ruhm, Christopher J. (2005), "Maternal Employment and Adolescent Development," Manuscript, University of North Carolina Greensboro.

Stafford, Frank P. (1987), “Women's Work, Sibling Competition and Children's School Performance.” American Economic Review, Vol. 77, No. 5, pp. 972-980.

Tougas, Jocelyne (2002), "Reforming Quebec's Early Childhood Care and Education: The First Five Years," Childcare Research and Research Unit Occasional Paper 17, University of Toronto.

Vandell, Dobrah L. and Janaki Ramanan, (1992), "Effects of Early and Recent Maternal Employment on Children from Low-Income Families" Child Development, Vol. 63, pp. 938-949.

Waldfogel , Jane, Wen-Jui Han, and Jeanne Brooks-Gunn (2002), "The Effects of Early Maternal Employment on Child Cognitive Development," Demography, Vol. 39, No. 2, pp. 369-392. 


\section{Appendix A: Family tax credits in Quebec and Canada}

\begin{tabular}{|c|c|}
\hline Program Name & Particulars \\
\hline Quebec Family Allowance & $\begin{array}{l}\text { Changed in } 1997 \text {, moved from universal allowances to income-tested and } \\
\text { targeted allowances. Family Allowance paid } \$ 975 \text { for children in two-parent } \\
\text { families and } \$ 2,275 \text { for children in lone-parent families. Reduced for family } \\
\text { income higher than } \$ 21,825 \text { for two-parent families and } \$ 15,332 \text { for lone- } \\
\text { parent families. }\end{array}$ \\
\hline Canada Child Tax Benefit & $\begin{array}{l}\text { National refundable credit, worth } \$ 1,020 \text { annually until } 1999 \text { (slightly more } \\
\text { since 2000). Reduced for family incomes greater than a threshold }(\$ 25,921 \\
\text { until 1999). }\end{array}$ \\
\hline $\begin{array}{l}\text { National Child Benefit } \\
\text { Supplement }\end{array}$ & $\begin{array}{l}\text { National refundable credit, introduced in } 1998 \text {, intially } \$ 605 \text { annually for } \\
\text { one child. Reduced for family incomes higher than threshold }(\$ 15,921 \\
\text { initially). Some provinces subtracted benefit from Social Assistance } \\
\text { payments. }\end{array}$ \\
\hline $\begin{array}{l}\text { National Child Benefit } \\
\text { Provincial Programs }\end{array}$ & $\begin{array}{l}\text { Some provinces introduced small earned income supplements or family } \\
\text { supplements as part of the National Child Benefit program. Structure varied } \\
\text { by province, but all income-tested. Timing varied by province. }\end{array}$ \\
\hline Social Assistance & $\begin{array}{l}\text { Social Assistance payments determined by provincial governments. Rates } \\
\text { varied by province and time. In some provinces, was partially integrated with } \\
\text { National Child Benefit program. }\end{array}$ \\
\hline
\end{tabular}

\section{Appendix B: Calculation of the subsidy variable}

We form our effective subsidy variable through simulations with a tax and benefit calculator. In this appendix we describe the calculator, the simulated individuals used for the calculations, and the formation of the final variable we use for our analysis.

\section{Fiscal assistance with childcare expenses}

The calculator incorporates all aspects of fiscal involvement with childcare expenses by families. Specifically, we consider:

- Federal Childcare Expense Deduction.

- Provincial subsidies for low income families.

- Quebec childcare credits.

We do not provide the complete detail necessary to recreate our result in this appendix because of space constraints. However, the full program parameters are available from the authors upon request. Below, we describe each component briefly and give a sense of the sources of variation.

The federal Childcare Expense Deduction allows qualifying childcare expenses to be 
deducted from the taxable income of the lower-earning spouse. This deduction affects the tax base for both provincial (non-Quebec) and federal income tax liabilities. The maximum deduction for children under age 8 was $\$ 4,000$ in 1992, \$5,000 from 1993 to 1997, and \$7,000 from 1998 to 2004.

The provincial subsidies are income-tested, and vary across province and through time. For brevity, we do not include the full parameters for the calculations in this appendix, but they are available from the authors upon request. The typical program gives a subsidy of a certain amount per child. The subsidy is then reduced for each dollar of family income over some threshold until the subsidy reaches zero. For example, a typical case is Alberta in 2000. A family with two parents and one toddler would receive an annual subsidy of $\$ 4,560$. The subsidy is reduced by 50 cents for each dollar of family income over $\$ 22,920$.

In Quebec, childcare expenses were treated as a deduction similar to the federal deduction up to 1993. In 1994, the deduction was replaced with a refundable tax credit. The credit refunded from $26 \%$ to $75 \%$ of qualifying expenses, with the rate depending on family income. The minimum $26 \%$ rate applied to incomes of $\$ 48,000$ and higher. The refundable credit system changed again in 2000 , although the credit was only payable to families not enrolled in the CPE $\$ 5$ per day program.

\section{Simulations to generate percent subsidy}

The various different ways of subsidizing childcare expenses interact in complicated ways. In order to capture this variation, we calculate for each province and year the average percentage of a family's childcare expenses that is paid by some level of government; that does not come out of the family's pocket. Because we want the presumably exogenous legislative variation across provinces and years to generate the variation in our subsidy measure, our strategy is to hold everything else constant across provinces and years. This strategy discards some of the variation in childcare subsidies, but allows us to focus on variation that we consider exogenous.

The base for our simulations is a set of families drawn from public-use versions of the annual Survey of Consumer Finances (1992 to 1995) and its successor the Survey of Labour and Income Dynamics (1996 to 2002). We select all families with at least one child under age 4 in which both parents are working, converting their incomes to constant year 2000 dollars. In order to keep the data set reasonably sized, we take a $10 \%$ sample of these families and proceed to reproduce each of the observations for every province-year combination. Through this procedure, the only difference between observations in different province-year combinations is the fiscal environment they face.

We assign each family a set level of childcare expenses and then proceed to calculate the percent of these expenses subsidized by governments through direct subsidies and tax subsidies. The annual amount of childcare expenses is assumed to be the same across all province-year combinations, at $\$ 5,724$ in year 1998 dollars. This number is drawn from Friendly, Beach, and Turiano (2002) Table 18, which reports the median 1998 cost of childcare for ages 0 to 17 months in Quebec to be $\$ 477$ per month, or $\$ 5724$ per year. While childcare expenses do vary across the country and through time, we want the simulations to embody purely legislative variation and so we discard the variation in subsidy levels induced by differing childcare prices. The direct subsidy assignment accounts for the provincial low-income subsidies and the Quebec Family Plan \$5 per day program. From these subsidy calculations, we arrive at a measure of out- 
of-pocket costs. The out-of-pocket costs are then used in an income tax calculation. The calculation is repeated for a family with and without childcare expenses to obtain the tax subsidy derived from the federal deduction and Quebec refundable childcare credit. When the direct subsidy is combined with the tax subsidy, we can calculate the percentage of childcare costs not paid by the family.

Percent Subsidy $=\frac{(\text { Direct subsidy }+ \text { Tax subsidy) }}{\text { Total Expense }}$

The final step in the calculation is to take the average of the percent subsidy variable over all the families in our simulation sample for each province-year combination. We do this separately for married and single families as well. The resulting set of variables embodies only the legislative differences across provinces and years; differences that we contend can be treated as exogenous to individual decisions.

\section{Appendix C: Components of the Aggregated Scores}

In the main body of the paper, we present results based on several aggregated indices for child and parental outcomes. In this appendix we describe the construction of these indices and present results for the individual components. More detail can be found in the user's guide for the NLSCY; this discussion draws from that source.

\section{Construction}

The indices are constructed for the NLSCY from qualitative responses to individual questions. For example, the Positive Interaction score is constructed from the responses to five individual questions. One of the individual questions is, "How often do you and [child's name] talk with each other, focusing attention on each other for five minutes or more, just for fun?" The responses range from 'never' to 'many times each day.' These qualitative responses are transformed to scores by assigning numerical values to each type of response. In this case, 'never' receives a 0 and 'many times each day' receives a 4, with intermediate responses receiving the values 1,2 , and 3 . The numerical values for the five questions are summed to arrive at the Positive Interaction score. Depending on the wording of the individual question, in some cases the scoring is reversed to ensure that increases in the individual component will correspond to increases in the index score. The user's guide for the NLSCY describes in detail the validation of the scales that are provided in the dataset.

In addition to the scores that are provided in the data set, we construct several scores of our own. This allows us to pool together children across age groups in order to facilitate comparisons across the age groups. The scores we create are pooled scores for aggressiveness, hyperactivity, and anxiety. We formed the scores as described above by summing numerical values across different questions in the survey, appropriately reversed in some cases to ensure the scores were cohesive. The survey questions we used in forming our scores are reported in the tables below. The scales we constructed have not been subject to the rigorous validation the NLSCY-provided scales were, so results should be interpreted with caution. 


\section{Individual Results}

Because the nature of the aggregation is somewhat arbitrary, and as a check that our results are not unduly driven by particular responses, we present the results for the individual questions that underlie the indices that we use. For these results, we coded binary dependent variables for each of the survey responses of interest. In order to make the results easier to interpret, we coded the 'good' response as 1 and the 'bad' response as ' 0 ', to the extent possible. This means that negative signs in the results indicate that exposure to the CPE program worsened outcomes, while positive signs indicate that outcomes improved. This convention we adopt has no impact on the aggregated index scores we report in the main text of the paper; it merely attempts to make the appendix tables easier to interpret.

In each of the three tables that follow, we report regression results from a difference-indifferences specification identical to those in the rest of the paper, using a binary eligibility indicator as the policy variable. Standard errors are reported below each estimate. We also report the results from our counterfactual sample, using age 6 to 11 children, but only for questions asked of children age 6-11. The tables also indicate for which index each survey question was a component.

The results generally show that the individual variables underlying the scores we use move in the same direction as the score itself in response to the CPE policy. For the child outcomes in Appendix Table I, 12 components are significantly negative at the 5 percent level, 10 are insignificant, and 1 are significantly positive. In contrast, for the results available in the counterfactual age 6-11 group, only 4 are significant and negative, while 9 are insignificant and 2 are positive and significant. For the parent variables in Appendix Table II, 10 are statistically significant and negative, while 6 are insignificant. The counterfactual age 6-11 estimates in Appendix Table II count 3 negative and significant results, 10 insignificant, and 3 positive and significant. Finally, for the motor-social development indicators in Appendix Table III, 5 of the variables are statistically significant and negative, 9 are insignificant, and just one is positive and significant. 


\section{Appendix Table I: Child outcome index component results}

\begin{tabular}{|c|c|c|c|c|c|c|c|c|c|}
\hline & Age $0-4$ & Age 6-11 & & & & ndexe & & & \\
\hline & DD & DD & (1) & (2) & (3) & (4) & $(5)$ & (6) & (7) \\
\hline $\begin{array}{l}\text { Never has problems sitting still, being } \\
\text { restless or hyperactive }\end{array}$ & $\begin{array}{l}-0.080 \\
(0.017)\end{array}$ & $\begin{array}{c}0.032 \\
(0.014)\end{array}$ & & & $\bullet$ & $\bullet$ & & & \\
\hline Never defiant & $\begin{array}{l}-0.114 \\
(0.021)\end{array}$ & & $\bullet$ & & & & & & \\
\hline Never unhappy, sad, or depressed & $\begin{array}{l}-0.008 \\
(0.019)\end{array}$ & $\begin{array}{l}0.040 \\
(0.017)\end{array}$ & & & & & - & - & \\
\hline Never gets into fights & $\begin{array}{l}-0.057 \\
(0.021)\end{array}$ & $\begin{array}{l}-0.021 \\
(0.025)\end{array}$ & & & & & & & \\
\hline $\begin{array}{l}\text { Never is distractible; has problems } \\
\text { sticking to an activity }\end{array}$ & $\begin{array}{l}0.065 \\
(0.015)\end{array}$ & $\begin{array}{c}0.094 \\
(0.014)\end{array}$ & & & & & & & \\
\hline Never as unhappy as others & $\begin{array}{c}0.007 \\
(0.010)\end{array}$ & $\begin{array}{l}-0.015 \\
(0.020)\end{array}$ & & & & & - & • & \\
\hline $\begin{array}{l}\text { Never cannot concentrate; cannot pay } \\
\text { attention for long }\end{array}$ & $\begin{array}{l}-0.064 \\
(0.014)\end{array}$ & $\begin{array}{c}0.029 \\
(0.018)\end{array}$ & & & & & & & \\
\hline Never Is too fearful or nervous & $\begin{array}{l}-0.120 \\
(0.017)\end{array}$ & $\begin{array}{l}-0.172 \\
(0.020)\end{array}$ & & & & & $\bullet$ & $\bullet$ & \\
\hline $\begin{array}{l}\text { Punishment doesn't change behavior: } \\
\text { never true }\end{array}$ & $\begin{array}{l}-0.043 \\
(0.017)\end{array}$ & & $\bullet$ & & & & & & \\
\hline Never is impulsive, acts without thinking & $\begin{array}{l}-0.067 \\
(0.023)\end{array}$ & $\begin{array}{l}-0.042 \\
(0.015)\end{array}$ & & & & & & & \\
\hline Never has temper tantrums or hot temper & $\begin{array}{l}-0.018 \\
(0.015)\end{array}$ & & $\bullet$ & & & & & & \\
\hline Never is worried & $\begin{array}{l}-0.080 \\
(0.014)\end{array}$ & $\begin{array}{l}-0.046 \\
(0.016)\end{array}$ & & & & & & $\bullet$ & \\
\hline Never has difficulty awaiting turn in games & $\begin{array}{l}-0.063 \\
(0.017)\end{array}$ & $\begin{array}{l}-0.012 \\
(0.023)\end{array}$ & $\bullet$ & & & & & & \\
\hline $\begin{array}{l}\text { When another child accidently hurts } \\
\text { him/her,never reacts in anger }\end{array}$ & $\begin{array}{l}-0.038 \\
(0.012)\end{array}$ & $\begin{array}{l}0.080 \\
(0.047)\end{array}$ & & & & & & & \\
\hline Never has angry moods & $\begin{array}{c}0.009 \\
(0.021)\end{array}$ & & $\bullet$ & & & & & & \\
\hline Never cries a lot & $\begin{array}{c}0.002 \\
(0.022)\end{array}$ & $\begin{array}{l}-0.011 \\
(0.017)\end{array}$ & & & & & & & $\bullet$ \\
\hline Never clings to adults or is too dependent & $\begin{array}{l}-0.030 \\
(0.026)\end{array}$ & & & & & & & & - \\
\hline Constantly seeks help: never true & $\begin{array}{c}0.001 \\
(0.025)\end{array}$ & & & & & & & & - \\
\hline Never is nervous, highstrung, tense & $\begin{array}{l}0.008 \\
(0.015)\end{array}$ & $\begin{array}{l}-0.069 \\
(0.020)\end{array}$ & & & & & & $\bullet$ & \\
\hline Never kicks, bites, hits other children & $\begin{array}{l}-0.071 \\
(0.011)\end{array}$ & $\begin{array}{l}-0.046 \\
(0.027)\end{array}$ & & & & & & & \\
\hline Doesn't want to sleep alone: never true & $\begin{array}{c}0.037 \\
(0.022)\end{array}$ & & & & & & & & - \\
\hline Never has trouble enjoying himself & $\begin{array}{c}0.015 \\
(0.011)\end{array}$ & $\begin{array}{c}0.002 \\
(0.016)\end{array}$ & & & & & & $\bullet$ & \\
\hline Never gets too upset when separated from parents & $\begin{array}{c}-0.064 \\
(0.025) \\
\end{array}$ & & & & & & & & - \\
\hline
\end{tabular}

Notes: Reported are coefficients on ELIG for separate regressions. Columns numbered (1) through (7) indicate whether the response is included in a particular index. The indexes are (1) Physical Aggression and Opposition, age 2-3 (2) Pooled aggression, age 2-11 (3) Hyperactivity and inattention score, age 2-3 (4) Pooled hyperactivity, age 2-11 (5) Emotional disorder / anxiety, age 2-3 (6) Pooled Anxiety, (7) Separation Anxiety. 


\section{Appendix Table II: Parent outcome index component results}

\begin{tabular}{|c|c|c|c|c|c|}
\hline \multirow[b]{3}{*}{ Gets annoyed with child once a week or less } & \multirow{2}{*}{$\begin{array}{l}\text { Age } 0-4 \\
\text { DD } \\
\end{array}$} & \multirow{2}{*}{$\begin{array}{l}\text { Age 6-11 } \\
\text { DD } \\
\end{array}$} & \multicolumn{3}{|c|}{ Indexes } \\
\hline & & & $(1)$ & $(2)$ & (3) \\
\hline & $\begin{array}{l}-0.046 \\
(0.018)\end{array}$ & $\begin{array}{c}0.034 \\
(0.018)\end{array}$ & $\bullet$ & & \\
\hline $\begin{array}{l}\text { Praise proportion when talking about } \\
\text { behavior is greater than half }\end{array}$ & $\begin{array}{l}-0.013 \\
(0.016)\end{array}$ & $\begin{array}{l}-0.013 \\
(0.019)\end{array}$ & $\bullet$ & & \\
\hline $\begin{array}{l}\text { Disapproval proportion when talking about } \\
\text { behavior is less than half }\end{array}$ & $\begin{array}{l}-0.044 \\
(0.022)\end{array}$ & $\begin{array}{l}-0.005 \\
(0.031)\end{array}$ & $\bullet$ & & \\
\hline $\begin{array}{l}\text { Makes sure child follows order or command } \\
\text { all the time }\end{array}$ & $\begin{array}{l}-0.080 \\
(0.025)\end{array}$ & $\begin{array}{c}0.001 \\
(0.013)\end{array}$ & & $\bullet$ & \\
\hline $\begin{array}{l}\text { When child doesn't stop doing something, } \\
\text { child is punished all the time }\end{array}$ & $\begin{array}{l}-0.041 \\
(0.016)\end{array}$ & $\begin{array}{c}0.023 \\
(0.028)\end{array}$ & & $\bullet$ & \\
\hline $\begin{array}{l}\text { Never gets away with something when } \\
\text { should have been punished }\end{array}$ & $\begin{array}{l}-0.006 \\
(0.007)\end{array}$ & $\begin{array}{l}-0.002 \\
(0.008)\end{array}$ & & $\bullet$ & \\
\hline Never get angry when punishing child & $\begin{array}{l}-0.046 \\
(0.021)\end{array}$ & $\begin{array}{l}-0.083 \\
(0.019)\end{array}$ & $\bullet$ & & \\
\hline $\begin{array}{l}\text { Never does the punishment depend on my } \\
\text { mood }\end{array}$ & $\begin{array}{l}-0.116 \\
(0.021)\end{array}$ & $\begin{array}{l}-0.048 \\
(0.018)\end{array}$ & $\bullet$ & & \\
\hline $\begin{array}{l}\text { Never have problems managing child in } \\
\text { general }\end{array}$ & $\begin{array}{l}-0.077 \\
(0.023)\end{array}$ & $\begin{array}{l}-0.063 \\
(0.020)\end{array}$ & $\bullet$ & & \\
\hline $\begin{array}{l}\text { Child never gets out of punishment when } \\
\text { child sets his/her mind to it }\end{array}$ & $\begin{array}{l}-0.088 \\
(0.014)\end{array}$ & $\begin{array}{l}-0.023 \\
(0.023)\end{array}$ & & $\bullet$ & \\
\hline Never ignores punishment & $\begin{array}{l}-0.026 \\
(0.021)\end{array}$ & $\begin{array}{l}-0.002 \\
(0.024)\end{array}$ & & $\bullet$ & \\
\hline Never must the punishment be repeated & $\begin{array}{l}-0.053 \\
(0.016)\end{array}$ & $\begin{array}{l}-0.026 \\
(0.015)\end{array}$ & $\bullet$ & & \\
\hline $\begin{array}{l}\text { Rarely or never raise voice, yell, or scold } \\
\text { when rules are broken }\end{array}$ & $\begin{array}{l}-0.072 \\
(0.013)\end{array}$ & $\begin{array}{l}0.070 \\
(0.022)\end{array}$ & & & $\bullet$ \\
\hline $\begin{array}{l}\text { Always or often calmly discuss problem } \\
\text { when rules are broken }\end{array}$ & $\begin{array}{l}-0.071 \\
(0.016)\end{array}$ & $\begin{array}{l}0.115 \\
(0.022)\end{array}$ & & & $\bullet$ \\
\hline $\begin{array}{l}\text { Never uses physical punishment when } \\
\text { rules are broken }\end{array}$ & $\begin{array}{l}-0.103 \\
(0.028)\end{array}$ & $\begin{array}{l}0.073 \\
(0.023)\end{array}$ & & & $\bullet$ \\
\hline $\begin{array}{l}\text { Always describe alternative behaviors } \\
\text { when rules are broken }\end{array}$ & $\begin{array}{c}0.012 \\
(0.019) \\
\end{array}$ & $\begin{array}{c}0.107 \\
(0.022) \\
\end{array}$ & & & $\bullet$ \\
\hline
\end{tabular}

Notes: Reported are coefficients on ELIG for separate regressions. Columns numbered (1) through (3) indicate whether the response is included in a particular index. The indexes, and the age ranges for which the indexes are reported, are: (1) Hostile / ineffective parenting, age 2-11 (2) Consistency, age 2-11 (3) Aversive parenting, age 2-11. 


\section{Appendix Table III: Motor Social Development}

\begin{tabular}{lc}
\hline \hline & ELIG \\
& DD \\
\cline { 2 - 2 } tells when soiiled pants - no crying & -0.028 \\
& $(0.021)$ \\
spoken a sentence of 3 words or more & -0.018 \\
& $(0.008)$ \\
has walked up stairs without holding rail & -0.017 \\
wash hands without help & $(0.006)$ \\
& -0.037 \\
has counted 3 objects correctly. & $(0.008)$ \\
& -0.021 \\
has gone to the toilet alone & $(0.013)$ \\
& -0.022 \\
walked upstairs without help, one foot one step & $(0.016)$ \\
know own age and sex & -0.053 \\
& $(0.012)$ \\
has said name of at least 4 colors & -0.029 \\
& $(0.018)$ \\
can pedal tricycle at least 10 feet & -0.036 \\
& $(0.020)$ \\
somersault without help & -0.092 \\
& $(0.017)$ \\
can dress himself without help & -0.016 \\
& $(0.019)$ \\
can say first and last name without help & -0.068 \\
can count out loud to 10 & $(0.024)$ \\
& -0.016 \\
& $(0.011)$ \\
& 0.033 \\
& $(0.012)$ \\
& 0.010 \\
& $(0.013)$ \\
\hline
\end{tabular}

Note: Reported are coefficients on ELIG in separate regressions. 
Figure 1: Regulated and Subsidized Spaces in Quebec

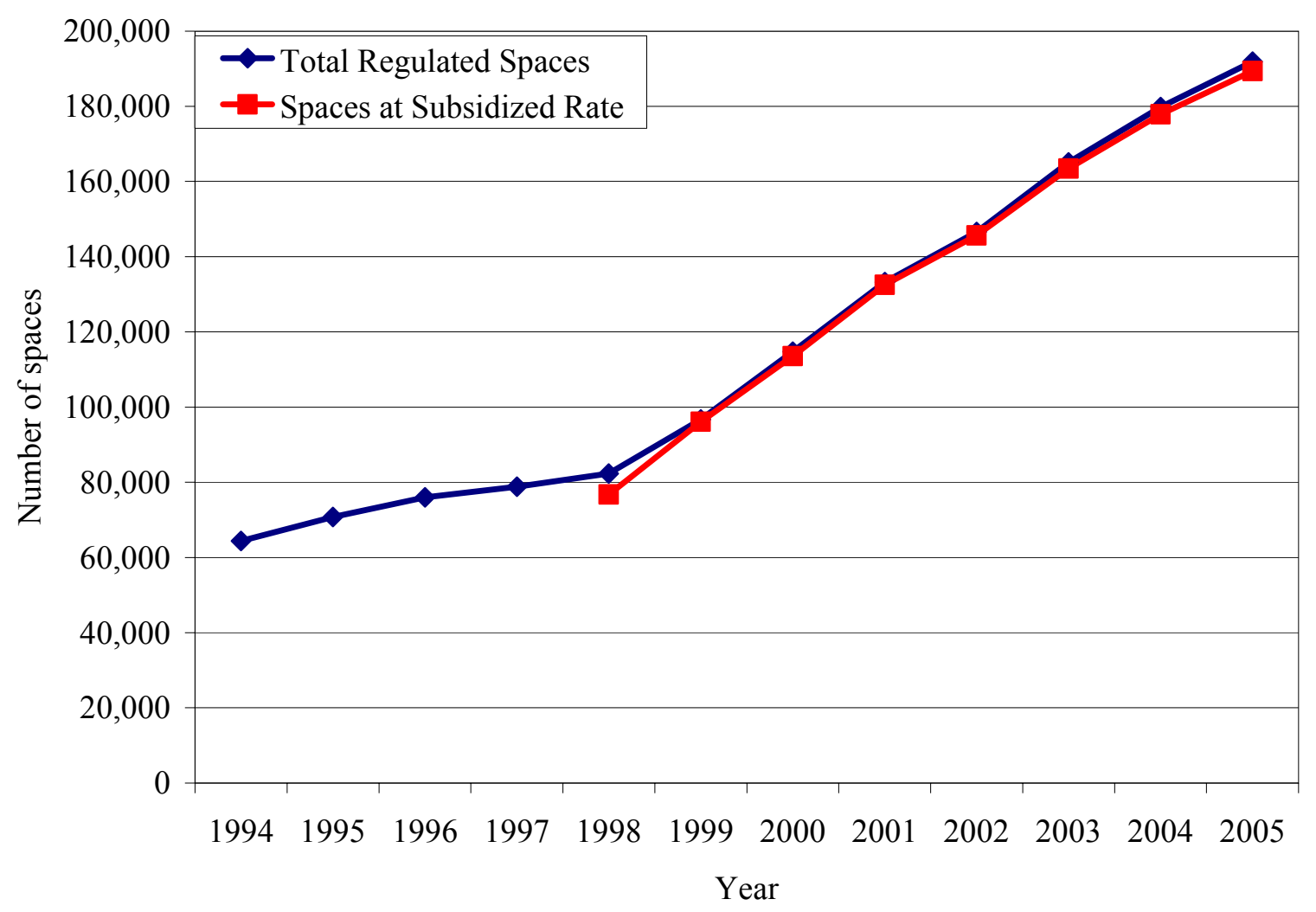

Notes: The number of spaces is for March 31 in the indicated year. This figure is adapted from Table 2 in Lefebvre and Merrigan (2005) and Quebec government statistics (for 2005). 
Figure 2: Percent Subsidy by Province

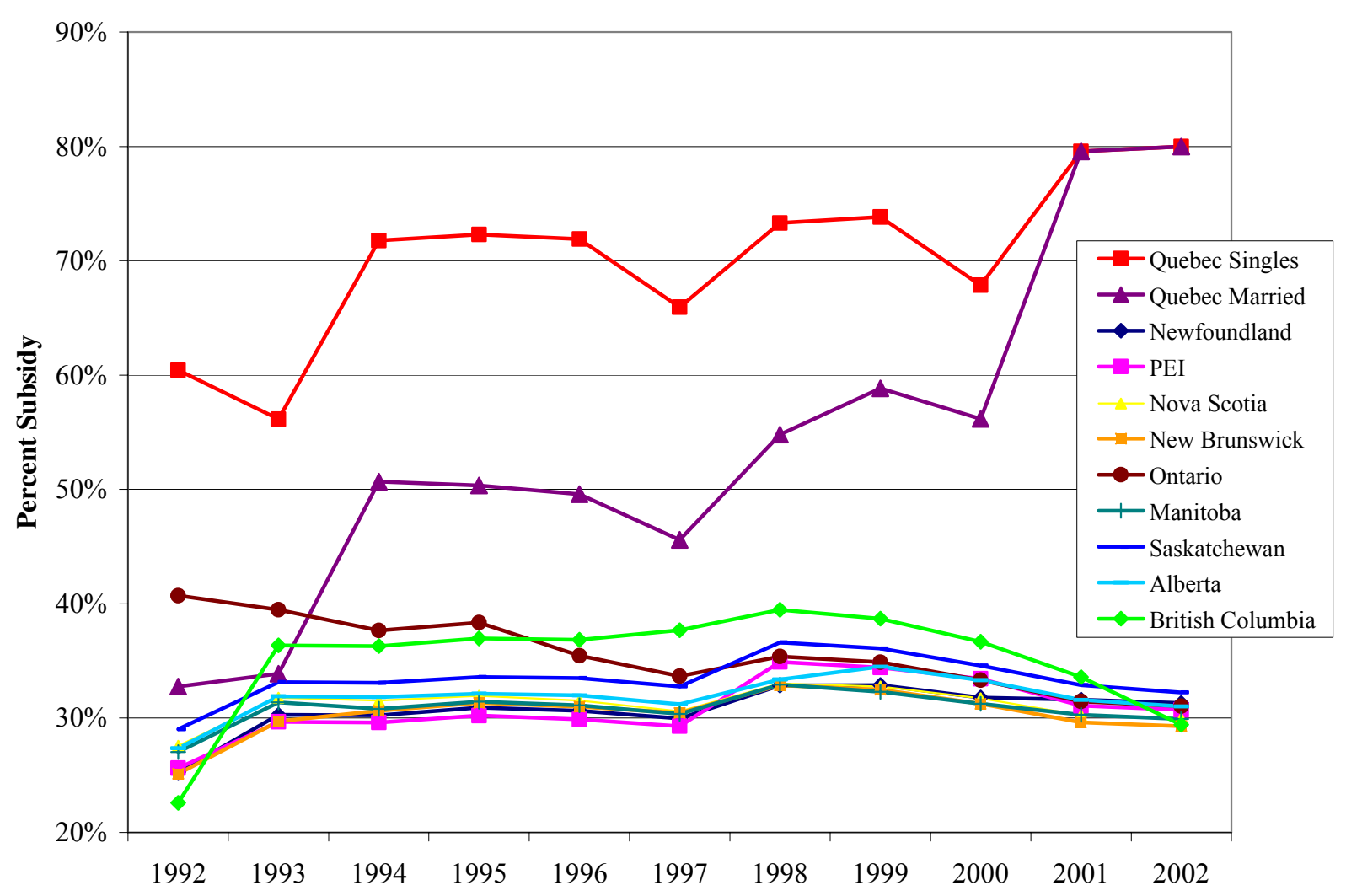

Notes: each data point represents a province-year mean of the percent subsidy variable over the families in the simulation sample. For al provinces, the subsidy rate for married couples is shown, as well as the subsidy rate for Quebec singles. 
Figure 3: In any Care, Ages 0-4

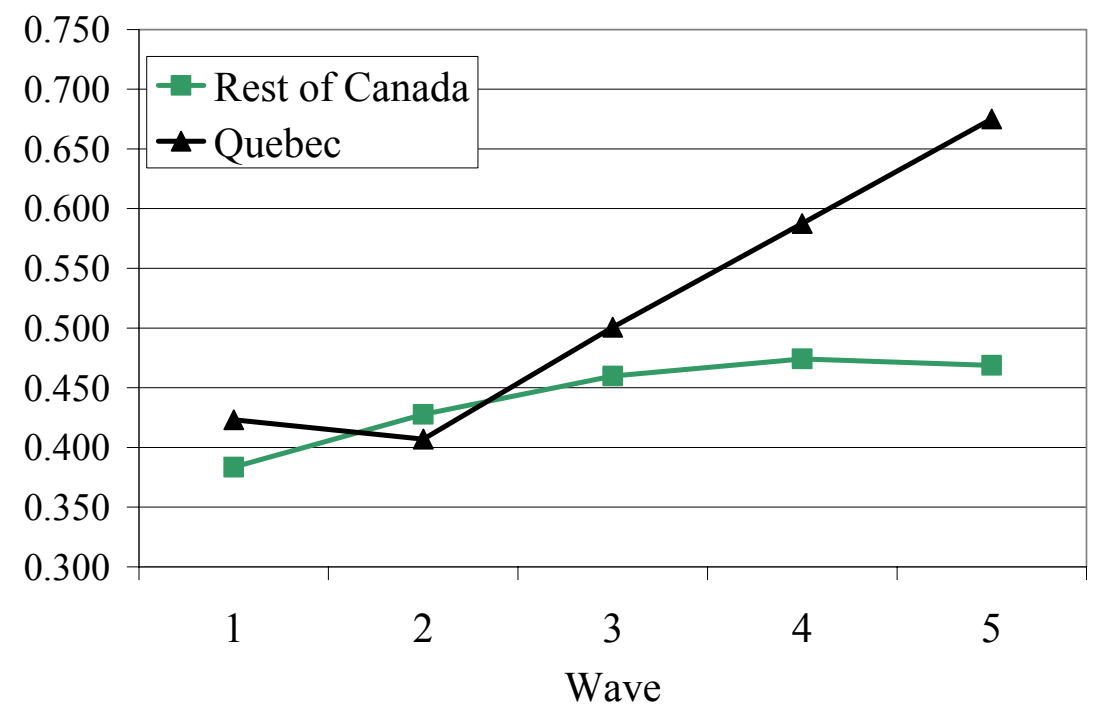

Figure 4: Mother Works, Ages 0-4

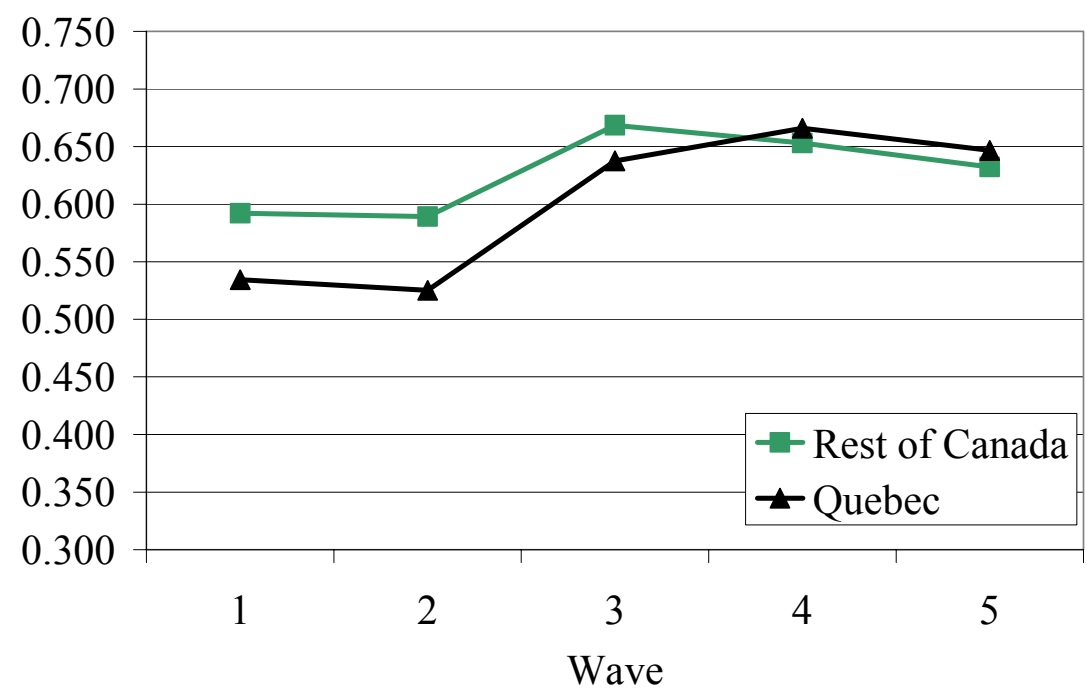




\section{Figure 5: Children's Outcomes}

Pooled Hyperactivity Score, Ages 2-4

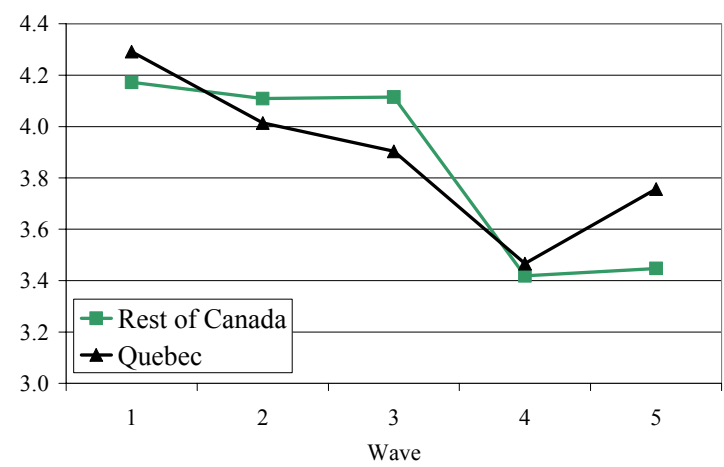

Pooled Aggression Score, Ages 2-4

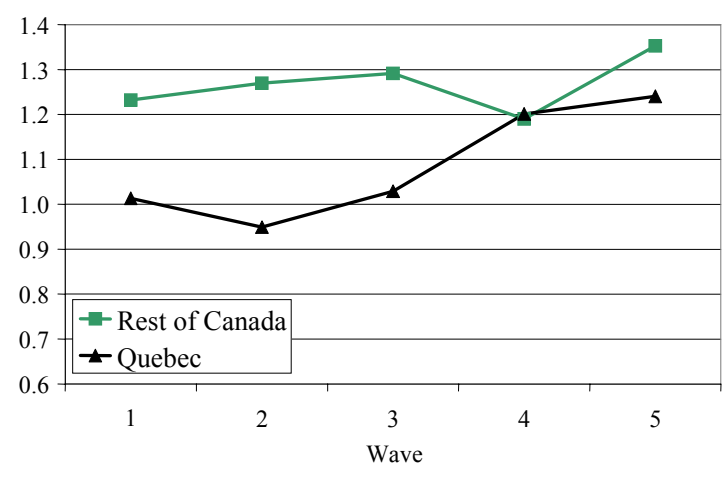

Pooled Anxiety Score, Ages 2-4

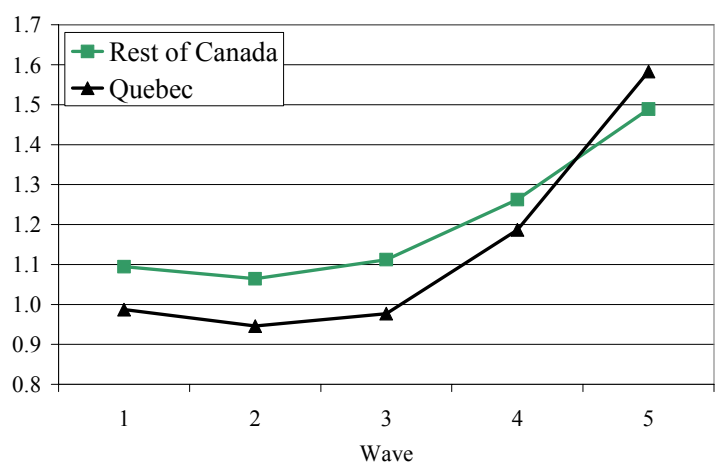

Child Never Has Nose or Throat Infections,

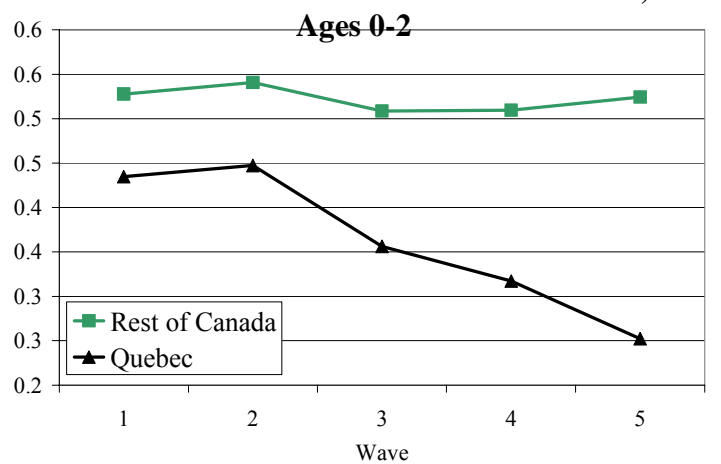




\section{Figure 6: Parents' Outcomes}

Hostile / Ineffective Parenting

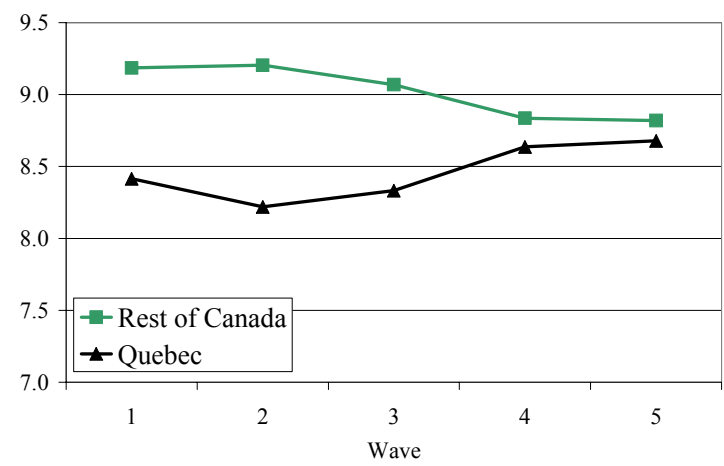

Aversive Parenting

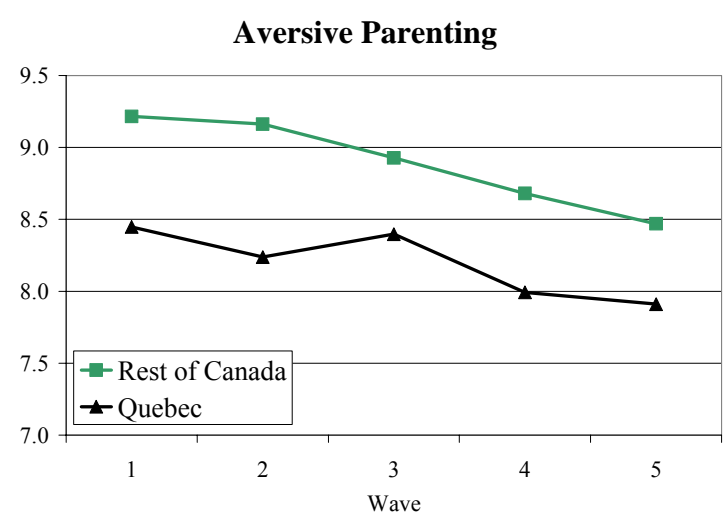

Consistency

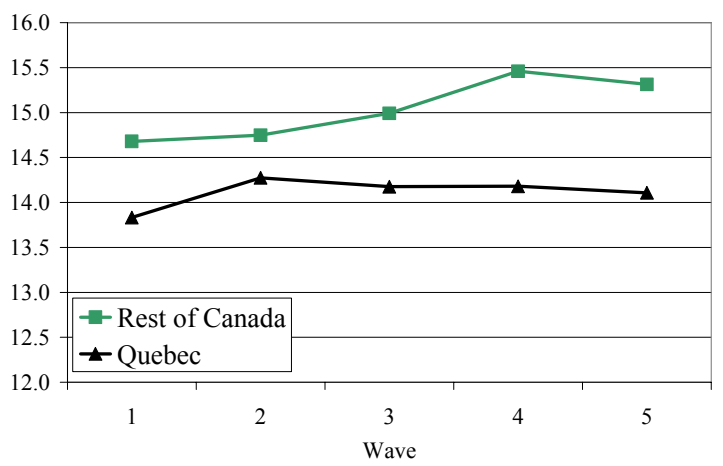


Table 1: Family Benefits in Ontario and Quebec 1992 to 2002

\begin{tabular}{|c|c|c|c|c|c|c|c|c|}
\hline \multirow[b]{2}{*}{ Year } & \multicolumn{2}{|c|}{ \$0 Earnings } & \multicolumn{2}{|c|}{$\$ 20,000$ Earnings } & \multicolumn{2}{|c|}{$\$ 40,000$ Earnings } & \multicolumn{2}{|c|}{$\$ 60,000$ Earnings } \\
\hline & Ontario & Quebec & Ontario & Quebec & Ontario & Quebec & Ontario & Quebec \\
\hline & \multicolumn{8}{|c|}{ Married Women } \\
\hline 1992 & 294 & 810 & 0 & 495 & 0 & 495 & 0 & 495 \\
\hline 1993 & 1,416 & 1,708 & 49 & 492 & 0 & 492 & 0 & 492 \\
\hline 1994 & 1,418 & 1,710 & 57 & 491 & 0 & 491 & 0 & 491 \\
\hline 1995 & 1,445 & 1,730 & 140 & 481 & 0 & 481 & 0 & 481 \\
\hline 1996 & 1,463 & 1,743 & 200 & 481 & 0 & 473 & 0 & 473 \\
\hline 1997 & 1,479 & 1,600 & 256 & 377 & 0 & 311 & 0 & 311 \\
\hline 1998 & 1,488 & 1,663 & 287 & 287 & 0 & 0 & 0 & 0 \\
\hline 1999 & 1,503 & 1,675 & 343 & 343 & 0 & 0 & 0 & 0 \\
\hline 2000 & 1,913 & 2,080 & 813 & 813 & 0 & 0 & 0 & 0 \\
\hline 2001 & 1,989 & 2,152 & 944 & 944 & 0 & 0 & 0 & 0 \\
\hline 2002 & 2,215 & 2,375 & 1,178 & 1,178 & 178 & 178 & 0 & 0 \\
\hline
\end{tabular}

\section{Single Women}

\begin{tabular}{ccccccccc}
1992 & 2,156 & 2,651 & 2,262 & 2,773 & 294 & 810 & 0 & 495 \\
1993 & 3,112 & 3,404 & 3,532 & 3,824 & 1,416 & 1,708 & 49 & 492 \\
1994 & 3,106 & 3,397 & 3,530 & 3,822 & 1,418 & 1,710 & 57 & 491 \\
1995 & 3,040 & 3,325 & 3,512 & 3,797 & 1,445 & 1,730 & 140 & 481 \\
1996 & 2,991 & 3,272 & 3,497 & 3,777 & 1,463 & 1,743 & 200 & 481 \\
1997 & 2,944 & 3,066 & 3,060 & 3,182 & 1,479 & 1,600 & 256 & 377 \\
1998 & 4,024 & 8,242 & 4,069 & 4,803 & 1,488 & 1,663 & 287 & 287 \\
1999 & 3,954 & 8,101 & 4,032 & 4,822 & 1,503 & 1,675 & 343 & 343 \\
2000 & 4,805 & 8,842 & 5,988 & 6,884 & 1,913 & 2,080 & 813 & 813 \\
2001 & 5,288 & 9,224 & 6,486 & 7,504 & 1,989 & 2,152 & 944 & 944 \\
2002 & 5,347 & 9,197 & 6,559 & 7,675 & 2,178 & 2,338 & 1,178 & 1,178 \\
\hline \hline
\end{tabular}

Note: Reported is the total federal and provincial refundable tax credits payable to families of each type. All dollar values are in 2002 Canadian dollars. The family is assumed to have two children, ages 3 and 8 . The husband is assumed to have earnings of $\$ 40,000$. 
Table 2: Program Impact on Childcare Use

\begin{tabular}{|c|c|c|c|c|c|c|c|c|}
\hline \multirow{3}{*}{$\frac{\text { Dependent Variables }}{\text { In any care }}$} & \multirow{3}{*}{$\frac{\text { Obs. }}{33,864}$} & \multirow{3}{*}{$\frac{\text { Means }}{0.415}$} & \multicolumn{3}{|c|}{ Base Specification } & \multirow{2}{*}{\multicolumn{3}{|c|}{$\begin{array}{c}\text { With Unemp. } \\
\text { ELIG } \\
\text { Dummy }\end{array}$}} \\
\hline & & & \multicolumn{2}{|c|}{$\begin{array}{c}\text { ELIG } \\
\text { Dummy } \\
\end{array}$} & \multirow{2}{*}{$\begin{array}{c}\text { Percent } \\
\text { Subsidy } \\
0.457 \\
(0.042)\end{array}$} & & & \\
\hline & & & $\begin{array}{c}0.147 \\
(0.016)\end{array}$ & $* * *$ & & $* * *$ & $\begin{array}{c}0.140 \\
(0.016)\end{array}$ & $* * *$ \\
\hline Hours per week & 33,389 & 13.7 & $\begin{array}{c}6.4 \\
(0.5)\end{array}$ & $* * *$ & $\begin{array}{l}19.6 \\
(1.5)\end{array}$ & $* * *$ & $\begin{array}{c}6.6 \\
(0.5)\end{array}$ & $* * *$ \\
\hline At least 20 hours per week & 33,389 & 0.303 & $\begin{array}{c}0.159 \\
(0.014)\end{array}$ & $* * *$ & $\begin{array}{c}0.486 \\
(0.043)\end{array}$ & $* * *$ & $\begin{array}{c}0.164 \\
(0.013)\end{array}$ & $* * *$ \\
\hline Institutional care & 33,864 & 0.110 & $\begin{array}{c}0.151 \\
(0.005)\end{array}$ & $* * *$ & $\begin{array}{c}0.464 \\
(0.021)\end{array}$ & $* * *$ & $\begin{array}{c}0.155 \\
(0.005)\end{array}$ & $* * *$ \\
\hline Care in own home & 33,864 & 0.072 & $\begin{array}{l}-0.008 \\
(0.007)\end{array}$ & & $\begin{array}{l}-0.023 \\
(0.023)\end{array}$ & & $\begin{array}{l}-0.008 \\
(0.007)\end{array}$ & \\
\hline Care in other's home & 33,864 & 0.230 & $\begin{array}{c}0.003 \\
(0.013)\end{array}$ & & $\begin{array}{c}0.014 \\
(0.041)\end{array}$ & & $\begin{array}{l}-0.008 \\
(0.014)\end{array}$ & \\
\hline \multicolumn{9}{|c|}{ Breakdown of care in other's home: } \\
\hline Licenced nonrelative & 33,864 & 0.044 & $\begin{array}{c}0.048 \\
(0.005)\end{array}$ & $* * *$ & $\begin{array}{c}0.143 \\
(0.018)\end{array}$ & $* * *$ & $\begin{array}{c}0.044 \\
(0.005)\end{array}$ & $* * *$ \\
\hline Non-licenced nonrelative & 33,864 & 0.135 & $\begin{array}{l}-0.023 \\
(0.012)\end{array}$ & $*$ & $\begin{array}{l}-0.062 \\
(0.038)\end{array}$ & & $\begin{array}{l}-0.025 \\
(0.012)\end{array}$ & $*$ \\
\hline Care in relative's home & 33,864 & 0.051 & $\begin{array}{l}-0.021 \\
(0.006)\end{array}$ & $* * *$ & $\begin{array}{l}-0.067 \\
(0.017)\end{array}$ & & $\begin{array}{l}-0.027 \\
(0.005)\end{array}$ & $* * *$ \\
\hline
\end{tabular}

Note: Reported are regression coefficients from separate regressions on data from the NLSCY. Standard errors are reported in parentheses. One, two, and there stars indicate statistical significance at the 10, 5, and 1 percent levels. Reported means are for Quebec over waves 1 and 2. 


\section{Table 3: Program Impact on Mother's Labor Supply}

\begin{tabular}{|c|c|c|c|c|c|c|c|c|c|c|}
\hline \multirow{4}{*}{$\frac{\text { Dependent Variables }}{\text { Mother works }}$} & \multirow{4}{*}{$\frac{\text { Obs. }}{33,788}$} & \multirow{4}{*}{$\frac{\text { Means }}{0.530}$} & \multirow{2}{*}{\multicolumn{3}{|c|}{ Base Specification }} & & \multicolumn{4}{|c|}{ Robustness checks } \\
\hline & & & & & & & \multirow{2}{*}{\multicolumn{2}{|c|}{$\begin{array}{l}\text { Age 6-11 } \\
\text { ELIG } \\
\text { Dummy } \\
\end{array}$}} & \multirow{2}{*}{\multicolumn{2}{|c|}{$\begin{array}{c}\text { With Unemp. } \\
\text { ELIG } \\
\text { Dummy } \\
\end{array}$}} \\
\hline & & & \multicolumn{2}{|c|}{$\begin{array}{l}\text { ELIG } \\
\text { Dummy } \\
\end{array}$} & \multirow{2}{*}{$\begin{array}{c}\text { Percent } \\
\text { Subsidy } \\
0.238 \\
(0.056)\end{array}$} & \multirow{2}{*}{$* * *$} & & & & \\
\hline & & & $\begin{array}{c}0.077 \\
(0.018)\end{array}$ & $* * *$ & & & $\begin{array}{c}0.007 \\
(0.027)\end{array}$ & & $\begin{array}{c}0.060 * \\
(0.018)\end{array}$ & $* *$ \\
\hline Mother's weeks of work & 33,833 & 27.2 & $\begin{array}{c}3.531 \\
(0.749)\end{array}$ & $* * *$ & $\begin{array}{l}11.139 \\
(2.131)\end{array}$ & $* * *$ & $\begin{array}{c}0.385 \\
(1.711)\end{array}$ & & $\begin{array}{l}3.044 * \\
(0.733)\end{array}$ & $* * *$ \\
\hline $\begin{array}{l}\text { Mother works at least } 20 \\
\text { hours / week }\end{array}$ & 33,860 & 0.536 & $\begin{array}{c}0.066 \\
(0.015)\end{array}$ & $* * *$ & $\begin{array}{c}0.207 \\
(0.045)\end{array}$ & $* * *$ & $\begin{array}{c}0.026 \\
(0.021)\end{array}$ & & $\begin{array}{c}0.063 * \\
(0.015)\end{array}$ & $* * *$ \\
\hline $\begin{array}{l}\text { Mother works at least } 30 \\
\text { hours / week }\end{array}$ & 33,860 & 0.428 & $\begin{array}{c}0.062 \\
(0.017)\end{array}$ & $* * *$ & $\begin{array}{c}0.193 \\
(0.052)\end{array}$ & $* * *$ & $\begin{array}{l}-0.038 \\
(0.028)\end{array}$ & & $\begin{array}{l}0.065 * \\
(0.018)\end{array}$ & $* * *$ \\
\hline $\begin{array}{l}\text { Mother works at least } 40 \\
\text { hours / week }\end{array}$ & 33,860 & 0.158 & $\begin{array}{c}0.000 \\
(0.012)\end{array}$ & & $\begin{array}{c}0.002 \\
(0.037)\end{array}$ & & $\begin{array}{l}-0.052 \\
(0.016)\end{array}$ & $* *$ & $\begin{array}{l}-0.009 \\
(0.012)\end{array}$ & \\
\hline Mother is in school & 33,565 & 0.127 & $\begin{array}{c}0.000 \\
(0.009)\end{array}$ & & $\begin{array}{l}-0.005 \\
(0.028)\end{array}$ & & $\begin{array}{l}-0.038 \\
(0.008)\end{array}$ & $* * *$ & $\begin{array}{c}0.000 \\
(0.009)\end{array}$ & \\
\hline Joint care and labor supply & y variab & & & & & & & & & \\
\hline $\begin{array}{l}\text { Mother works / child } \\
\text { in care }\end{array}$ & 33,634 & 0.356 & $\begin{array}{c}0.126 \\
(0.016)\end{array}$ & $* * *$ & $\begin{array}{c}0.391 \\
(0.046)\end{array}$ & $* * *$ & -- & & $\begin{array}{l}0.117 * \\
(0.017)\end{array}$ & $* * *$ \\
\hline Mother works / no care & 33,634 & 0.173 & $\begin{array}{l}-0.049 \\
(0.010)\end{array}$ & $* * *$ & $\begin{array}{l}-0.152 \\
(0.029)\end{array}$ & $* * *$ & -- & & $\begin{array}{l}-0.056 * \\
(0.009)\end{array}$ & $* * *$ \\
\hline $\begin{array}{l}\text { Mother not work / child } \\
\text { in care }\end{array}$ & 33,634 & 0.059 & $\begin{array}{c}0.023 \\
(0.005)\end{array}$ & $* * *$ & $\begin{array}{c}0.070 \\
(0.014)\end{array}$ & $* * *$ & -- & & $\begin{array}{l}0.025 * \\
(0.005)\end{array}$ & $* * *$ \\
\hline Mother not work / no care & 33,634 & 0.412 & $\begin{array}{l}-0.100 \\
(0.017)\end{array}$ & $* * *$ & $\begin{array}{l}-0.309 \\
(0.050)\end{array}$ & $* * *$ & -- & & $\begin{array}{l}-0.085 * \\
(0.017)\end{array}$ & $* * *$ \\
\hline
\end{tabular}

Note: Reported are regression coefficients from separate regressions on data from the NLSCY. Standard errors are reported in parentheses. One, two, and there stars indicate statistical significance at the 10,5 , and 1 percent levels. Details on the specifications are provided in the main text. Reported means are for Quebec over waves 1 and 2, for children age 0-4. Reported observations are for the age 0 . 4 sample. 


\section{Table 4: Program Impact on Child's Behavior and Health}

\begin{tabular}{|c|c|c|c|c|c|c|c|c|}
\hline \multirow[b]{3}{*}{ Dependent Variables } & \multirow[b]{3}{*}{ Obs. } & & & & \multicolumn{4}{|c|}{$\begin{array}{l}\text { Robustness checks } \\
\end{array}$} \\
\hline & & \multicolumn{3}{|c|}{ Base Specification } & Age 6-11 & & \multirow{2}{*}{\multicolumn{2}{|c|}{$\begin{array}{c}\text { With Unempl. } \\
\text { ELIG } \\
\text { Dummy }\end{array}$}} \\
\hline & & Means & $\begin{array}{c}\text { ELIG } \\
\text { Dummy }\end{array}$ & & $\begin{array}{c}\text { ELIG } \\
\text { Dummy }\end{array}$ & & & \\
\hline $\begin{array}{l}\text { Hyper activity - inattention } \\
\text { ages } 2-3\end{array}$ & 14,494 & 4.102 & $\begin{array}{c}0.101 \\
(0.078)\end{array}$ & & -- & & $\begin{array}{c}0.142 \\
(0.078)\end{array}$ & \\
\hline $\begin{array}{l}\text { Pooled hyperactivity score } \\
\text { ages } 2-4 \& \text { ages } 6-11\end{array}$ & 20,139 & 4.156 & $\begin{array}{c}0.143 \\
(0.056)\end{array}$ & $* *$ & $\begin{array}{l}-0.096 \\
(0.129)\end{array}$ & & $\begin{array}{c}0.210 \\
(0.066)\end{array}$ & $* *$ \\
\hline $\begin{array}{l}\text { Emotional Disorder - Anxiety } \\
\text { Score, ages 2-3 }\end{array}$ & 14,555 & 0.967 & $\begin{array}{c}0.118 \\
(0.060)\end{array}$ & $*$ & -- & & $\begin{array}{c}0.062 \\
(0.053)\end{array}$ & \\
\hline $\begin{array}{l}\text { Pooled anxiety score } \\
\text { ages 2-4 \& ages 6-11 }\end{array}$ & 20,209 & 1.083 & $\begin{array}{c}0.234 \\
(0.068)\end{array}$ & $* * *$ & $\begin{array}{c}0.308 \\
(0.080)\end{array}$ & $\star * *$ & $\begin{array}{c}0.190 \\
(0.060)\end{array}$ & $* *$ \\
\hline $\begin{array}{l}\text { Separation anxiety score } \\
\text { Ages } 2-3\end{array}$ & 14,580 & 2.668 & $\begin{array}{c}0.094 \\
(0.088)\end{array}$ & & -- & & $\begin{array}{c}0.108 \\
(0.091)\end{array}$ & \\
\hline $\begin{array}{l}\text { Physical aggression/opposition } \\
\text { age } 2-3\end{array}$ & 14,435 & 4.375 & $\begin{array}{c}0.384 \\
(0.119)\end{array}$ & $* *$ & -- & & $\begin{array}{c}0.277 \\
(0.112)\end{array}$ & $* *$ \\
\hline $\begin{array}{l}\text { Pooled aggressiveness score } \\
\text { ages } 2-4 \& \text { ages } 6-11\end{array}$ & 20,213 & 0.982 & $\begin{array}{c}0.189 \\
(0.046)\end{array}$ & $* * *$ & $\begin{array}{l}-0.013 \\
(0.113)\end{array}$ & & $\begin{array}{l}0.139 \\
0.043\end{array}$ & $* *$ \\
\hline $\begin{array}{l}\text { Standardized motor and social } \\
\text { development score, ages } 0-3\end{array}$ & 26,140 & 99.317 & $\begin{array}{l}-1.626 \\
(0.346)\end{array}$ & $* * *$ & -- & & $\begin{array}{c}-1.8123 \\
0.380\end{array}$ & $* * *$ \\
\hline $\begin{array}{l}\text { PPVT Score, scaled } \\
\text { age } 4\end{array}$ & 5,210 & 100.78 & $\begin{array}{c}0.46 \\
(1.30)\end{array}$ & & -- & & $\begin{array}{c}0.05 \\
(1.37)\end{array}$ & \\
\hline $\begin{array}{l}\text { In general, child is in excellent } \\
\text { health. Ages } 0-4 \text { \& 6-11. }\end{array}$ & 33,891 & 0.641 & $\begin{array}{l}-0.053 \\
(0.013)\end{array}$ & $* * *$ & $\begin{array}{l}-0.026 \\
(0.018)\end{array}$ & & $\begin{array}{l}-0.060 \\
(0.013)\end{array}$ & $* * *$ \\
\hline $\begin{array}{l}\text { Child has been injured in past } \\
12 \text { months. Ages } 0-4 \text { \& 6-11. }\end{array}$ & 33,878 & 0.071 & $\begin{array}{c}0.005 \\
(0.005)\end{array}$ & & $\begin{array}{l}-0.028 \\
(0.009)\end{array}$ & $* *$ & $\begin{array}{c}0.003 \\
(0.005)\end{array}$ & \\
\hline $\begin{array}{l}\text { Had asthma attack in past } 12 \\
\text { months. Ages } 0-4,6-11 \text {. }\end{array}$ & 33,867 & 0.045 & $\begin{array}{l}-0.003 \\
(0.004)\end{array}$ & & $\begin{array}{l}-0.021 \\
(0.015)\end{array}$ & & $\begin{array}{l}-0.005 \\
(0.004)\end{array}$ & \\
\hline $\begin{array}{l}\text { Child never has nose or throat } \\
\text { infections. Ages } 0-2 \text {. }\end{array}$ & 19,931 & 0.441 & $\begin{array}{l}-0.134 \\
(0.023)\end{array}$ & $* * *$ & -- & & $\begin{array}{l}-0.143 \\
(0.022)\end{array}$ & $* * *$ \\
\hline $\begin{array}{l}\text { Child has never had an ear } \\
\text { infection. Ages } 0-2 \text {. }\end{array}$ & 19,923 & 0.502 & $\begin{array}{l}-0.051 \\
(0.011)\end{array}$ & $* * *$ & -- & & $\begin{array}{l}-0.057 \\
(0.011)\end{array}$ & $* * *$ \\
\hline
\end{tabular}

Note: Reported are regression coefficients from separate regressions on data from the NLSCY. Standard errors are reported in parentheses. One, two, and there stars indicate statistical significance at the 10,5, and 1 percent levels. Details on the specifications are provided in the main text. Reported means are for Quebec over waves 1 and 2, for children age 0-4. Reported observations are for the age $0-4$ sample. 


\section{Table 5: Program Impact on Parents' Behavior and Health}

\begin{tabular}{|c|c|c|c|c|c|c|c|}
\hline \multirow{4}{*}{ Dependent Variables } & \multirow{4}{*}{ Obs. } & & & & \multicolumn{3}{|c|}{$\begin{array}{c}\text { Robustness Checks } \\
\end{array}$} \\
\hline & & \multicolumn{3}{|c|}{ Base Specification } & $\overline{\text { Age 6-11 }}$ & \multirow{3}{*}{\multicolumn{2}{|c|}{$\begin{array}{l}\text { With Unempl. } \\
\text { ELIG } \\
\text { Dummy }\end{array}$}} \\
\hline & & Menn & ELIG & & $\overline{\text { ELIG }}$ & & \\
\hline & & Means & Dummy & & & & \\
\hline $\begin{array}{l}\text { Hostile, ineffective parentin } \\
\text { Ages } 2-4 \text { \& ages 6-11. }\end{array}$ & 20,017 & 8.320 & $\begin{array}{c}0.721 \\
(0.220)\end{array}$ & $* *$ & $\begin{array}{l}0.261 * \\
(0.138)\end{array}$ & $\begin{array}{c}0.586 \\
(0.231)\end{array}$ & $* *$ \\
\hline $\begin{array}{l}\text { Consistency } \\
\text { Ages 2-4 \& ages 6-11. }\end{array}$ & 19,809 & 14.048 & $\begin{array}{l}-0.501 \\
(0.159)\end{array}$ & $* *$ & $\begin{array}{c}0.111 \\
(0.167)\end{array}$ & $\begin{array}{l}-0.734 \\
(0.198)\end{array}$ & $* * *$ \\
\hline $\begin{array}{l}\text { Aversive parenting } \\
\text { Ages } 2-4 \text { \& ages } 6-11 .\end{array}$ & 20,116 & 8.346 & $\begin{array}{c}0.186 \\
(0.074)\end{array}$ & $* *$ & $\begin{array}{l}-0.106 \\
(0.096)\end{array}$ & $\begin{array}{c}0.133 \\
(0.073)\end{array}$ & \\
\hline $\begin{array}{l}\text { Mother health status } \\
\text { is excellent. Ages 0-4 \& 6-1 }\end{array}$ & $\begin{array}{l}33,708 \\
1 .\end{array}$ & 0.406 & $\begin{array}{l}-0.011 \\
(0.013)\end{array}$ & & $\begin{array}{l}-0.039 \\
(0.022)\end{array}$ & $\begin{array}{l}-0.006 \\
(0.012)\end{array}$ & \\
\hline $\begin{array}{l}\text { Father health status } \\
\text { is excellent. Ages 0-4 \& 6-1 }\end{array}$ & $\begin{array}{l}33,586 \\
1 .\end{array}$ & 0.449 & $\begin{array}{l}-0.028 \\
(0.011)\end{array}$ & $* *$ & $\begin{array}{l}-0.020 \\
(0.025)\end{array}$ & $\begin{array}{l}-0.021 \\
(0.010)\end{array}$ & $*$ \\
\hline $\begin{array}{l}\text { Mother depression score } \\
\text { Ages 0-4 \& 6-11. }\end{array}$ & 29,595 & 4.199 & $\begin{array}{c}0.428 \\
(0.108)\end{array}$ & $* * *$ & $\begin{array}{l}-0.223 \\
(0.330)\end{array}$ & $\begin{array}{c}0.460 \\
(0.108)\end{array}$ & $* * *$ \\
\hline $\begin{array}{l}\text { Satisfaction with relationshi } \\
\text { Ages } 0-4 \& 6-11 \text {. }\end{array}$ & 26,473 & 9.351 & $\begin{array}{l}-0.193 \\
(0.059)\end{array}$ & $* *$ & $\begin{array}{c}0.034 \\
(0.151)\end{array}$ & $\begin{array}{l}-0.192 \\
(0.059)\end{array}$ & $* *$ \\
\hline
\end{tabular}

Note: Reported are regression coefficients from separate regressions. Standard errors are reported in parentheses. One, two, and there stars indicate statistical significance at the 10, 5, and 1 percent levels. Reported means are for Quebec over waves 1 and 2, for children age 04. Reported observations are for the age 0-4 sample. 